\title{
KEBIJAKAN PENGELOLAAN PULAU KECIL PERBATASAN BERBASIS GEOPOLITIK, DAYA DUKUNG EKONOMI DAN LINGKUNGAN (Kasus Pulau Pulau Kecil Perbatasan Kepulauan Sangihe, Sulawesi Utara)
}

\author{
(POLICY ON MANAGEMENT OF NEIGHBORING STATE SMALL ISLANDS \\ (Case of Sangihe Archipelago, North Sulawesi))
}

\author{
Achmad Nasir Biasane ${ }^{1}$; Akhmad Fauzi; Daniel R. Monintja ${ }^{2}$; Dedi Soedharma \\ ${ }^{1}$ Corresponding author \\ ${ }^{2}$ Departemen Pemanfaatan Sumberdaya Perikanan, FPIK-IPB \\ E-mail : nasirbiasanegic@.gmail.com
}

\begin{abstract}
Execution of Sipadan and Ligitan islands by International Court of Justice as the part of sovereignity of Malaysia based on effective occupation, have encouraged Indonesia to be more aware and care for developing the neighboring state small islands. There are many national and regional institutions have developed programs and activities for the neighboring state small island but the programs still sector and partial oriented, whereas no national policy yet concerning the neighboring state small islands management. This research was to formulate comprehensive policy for the management of neighboring state small islands of Sangihe archipelago based on geo-politic, economic and environment carrying capacity. Specific objective were: (1) to evaluate and formulate of management policy for neighboring small islands of Sangibe archipelgo based on geo-politic, and (2) to evaluate economic and environment carrying capacity for formulate input of neighboring small islands management policy in Sangibe Archipelagic. The research was conducted Archipelagic in Regency of Sangibe, North Sulawesi Province. Primary data collected at Tahuna, Marore Island, Matutuang Island, Tinakareng Island, and Kawio Island. Secondary data collected since proposal developing until data analysis. Results of the study show that the potential sectors to be developed for Sangibe are capture fisheries and estate commodities. This research to develop of capture fisheries on analysis, basically the scads fish (Decapterus sp.), trvevallies (Selar spp.), eastern little tuna (Euthynus sp.), skipjack tuna (Katsuwomus pelamis), shark (Charcarias sp.) and tuna (Thunnus albacares). The average sustainable production of the scad fish 20 years (1988-2007) observation 1s 1746,3 tons/year, trevallies is 194,1 tons/year, sharks is 148,4 tons/year, skipjack tuna is 315,6 tons/year, tuna is 152 tons/year, and estern little tuna is 1073,2 tons/year on the same period. The priorities of neighboring small island policies are: (1) development of capture fisheries, coconut and nutmeg estate; (2) demarcation and delimitation of boundary state; (3) develop system of defence and security in the neighboring state small islands; (4) the change of agreement of border trade base on economic value; and (5) optimal and sustainable utilization of natural resource.
\end{abstract}

Keywords: Neighboring state small island of Sangihe archipelago; shift share, LQ, CYP, SWOT, AHP, MAPLE, development of the large pelagic fishes, and A'WOT

\begin{abstract}
ABSTRAK
Pulau Sipadan dan Ligitan sebagai bagian dari kedaulatan Malaysia ditetapkan oleh Mahkamah Internasional berdasarkan keberadaannya, telah mendorong Indonesia untuk lebih sadar dan peduli untuk mengembangkan pulau-pulau kecil perbatasan. Terdapat lembaga-lembaga nasional dan regional telah mengembangkan program dan kegiatan untuk pulau kecil perbatasan tapi program masih berorientasi sektoral dan parsial, sedangkan tidak ada kebijakan nasional mengenai manajemen pulau kecil perbatasan. Penelitian ini bertujuan untuk merumuskan kebijakan yang komprehensif untuk pengelolaan pulau-pulau kecil kepulauan Sangihe berdasarkan geo-politik, ekonomi dan daya dukung lingkungan. Penelitian dilakukan di Kabupaten Kepulauan Sangihe, Provinsi Sulawesi Utara. Data primer dikumpulkan di Tahuna, Pulau Marore, Pulau Matutuang, Pulau Tinakareng, dan Pulau Kawio. Hasil penelitian menunjukkan bahwa sektor potensial untuk dikembangkan di Kepulauan Sangihe adalah perikanan tangkap dan komoditas perkebunan. Penelitian ini melakukan analisis untuk mengembangkan perikanan tangkap pada ikan layang (Decapterus sp.), trvevallies (Selar spp.), tuna kecil (Euthynus sp.), Skipjack tuna (Katsunomus pelamis), hiu (Charcarias sp.) dan tuna (Thunnus albacares). Produksi berkelanjutan rata-rata pada 20 tahun (1988-2007) ikan layang adalah 1746,3 ton/tahun, bobara adalah 194,1 ton/tahun, hiu adalah 148,4 ton/tahun, ikan tuna cakalang adalah 315,6 ton/tahun, tuna adalah 152 ton/tahun, dan tuna kecil adalah 1073,2 ton/tahun pada periode yang sama. Prioritas kebijakan pulau kecil perbatasan adalah: (1) pengembangan perikanan tangkap, kelapa dan pala real, (2) demarkasi dan delimitasi batas negara, (3) mengembangkan sistem pertahanan dan keamanan di pulau-pulau kecil, (4 ) perubahan perjanjian dasar perdagangan terhadap perbatasan nilai ekonomi; dan (5) pemanfaatan optimal dan berkelanjutan sumber daya alam.
\end{abstract}

Kata kunci: Pulau-pulau kecil, LQ, CYP, SWOT, AHP, MAPLE, pengembangan ikan pelagis, dan A'WOT 


\section{PENDAhUlUaN}

Dalam peta teritorial Negara Kesatuan Republik Indonesia (NKRI), Kabupaten Kepulauan Sangihe merupakan salah satu kabupaten yang menempati posisi paling utara dan berbatasan langsung dengan negara tetangga Filipina serta berada di Laut Sulawesi dan pinggiran Samudera Pasifik. Letak geografis tersebut menempatkan posisi kabupaten ini memiliki nilai strategis, mengingat besarnya peluang melakukan kerjasama interregional - internasional yang berpengaruh terhadap akses pasar global. Pada sisi lain juga mengandung kerawanan-kerawanan tertentu, antara lain: infiltrasi idiologi asing, terorisme internasional, penyelundupan, pencurian sumber daya alam (SDA), dan berbagai kegiatan illegal lainnya. Kedudukan pulau-pulau kecil (P2K) Perbatasan Kepulauan Sangihe memiliki aspek penting sebagai pita pengamanan nasional (security national belt) ditinjau dari perspektif keamanan nasional, serta secara geopolitik ikut menentukan Indonesia sebagai Negara Kepulauan (Archipelagic State). Hal ini disebabkan Kepulauan Sangihe memiliki 5 (lima) pulau sebagai pulau terluar dan perbatasan, yaitu: Pulau Marore, P. Kawio, P. Matutuang, P. Kawaluso, dan Pulau Lipang.

Kabupaten Kepulauan Sangihe Talaud, di masa kolonial Belanda disebut sebagai noorden einlanden yang diterjemahkan sebagai "Nusa Utara". Istilah ini berawal dari perjalanan Gubernur Maluku Robertus Padtbrugge (16 Agustus - 25 Desember 1677), yang dilandasi oleh kepentingan geopolitik dan geoekonomi pemerintah Hindia Belanda. Padtbrugge merubah kiblat pendidikan, perdagangan, dan hubungan kekerabatan yang semula ke Ternate dan Filipina diarahkan ke wilayah daratan Sulawesi terutama ke Manado. Saat ini Kabupaten Kepulauan Sangihe Talaud telah dimekarkan menjadi tiga kabupaten yaitu: Kabupaten Kepulauan Sangihe (kabupaten induk), Kabupaten Kepulauan Talaud (UU No. 5/2002), dan Kabupaten Kepulauan Sitaro yang merupakan gabungan tiga pulau yaitu P. Siau, P. Tagulandang, dan P. Biaro (UU No. 15/2007).
P2K Perbatasan Kepulauan Sangihe, selama ini kurang memperoleh sentuhan pembangunan, disebabkan beberapa alasan, yaitu: (1) kebanyakan P2K Perbatasan tidak berpenghuni karena ukuran relatif kecil; kalaupun berpenghuni, jumlah penduduknya sangat sedikit sehingga tidak menjadi prioritas utama; (2) kawasan ini cenderung terisolasi sehingga diperlukan investasi yang besar (high cost investment) untuk membangun prasarana dan sarana perhubungan laut; (3) pembangunan nasional selama ini lebih berorientasi ke darat; (4) rendahnya tingkat pendidikan masyarakat setempat; (5) kurang minatnya dunia usaha berinvestasi; (6) pilihan pengelolaan ekonomi menjadi terbatas karena ukuran (luas) P2K dan lokasi yang jauh (remote) serta terbelakang; dan (7) kecilnya skala ekonomi dalam hal aktivitas produksi, transportasi, konsumsi dan administrasi.

Atas dasar kepentingan mendesak untuk melihat sejauh mana posisi geografis dan potensi SDA di P2K Perbatasan Kepulauan Sangihe dapat memberikan kontribusi terhadap pembangunan nasional dan kesejahteraan masyarakat, maka dirumuskan pertanyaan penelitian, sebagai berikut:

(1) Sektor/subsektor apa saja yang memberikan kontribusi terbesar terhadap perkembangan ekonomi Kepulauan Sangihe sebagai Kawasan Perbatasan?

(2) Bagaimana daya dukung ekonomi dan lingkungan SDA dijadikan bahan pertimbangan dalam merumuskan kebijakan pengelolaan P2K Perbatasan Kepulauan Sangihe?, dan

(3) Bagaimana rumusan kebijakan pengelolaan P2K Perbatasan Kepulauan Sangihe yang berbasis geopolitik, daya dukung ekonomi dan lingkungan?.

\subsection{Tujuan dan Manfaat Penelitian}

Penelitian ini secara umum bertujuan merumuskan alternatif kebijakan dan program pengelolaan P2K Perbatasan Kepulauan Sangihe berbasis geopolitik, daya dukung ekonomi dan lingkungan. Secara khusus, penelitian ini bertujuan:

(1) Mempelajari sektor/subsektor serta komoditas yang memberikan kontribusi terbesar terhadap 
perkembangan perekonomian di Kepulauan Sangihe sebagai Kawasan Perbatasan;

(2) Menganalisis dan mengevaluasi daya dukung ekonomi dan lingkungan SDA saat ini sebagai bahan pertimbangan dalam penyusunan pola pengembangan P2K Perbatasan Kepulauan Sangihe; dan

(3) Mengevaluasi dan merumuskan kebijakan pengelolaan P2K Perbatasan Kepulauan Sangihe yang berbasis geopolitik, daya dukung ekonomi dan lingkungan.

\section{METODOLOGI PENELITIAN}

\subsection{Wilayah Penelitian dan Ruang Lingkup Penelitian}

Penelitian dilakukan sejak bulan April 2007 sampai dengan bulan Desember 2009 (termasuk penulisan disertasi). Penelitian berlokasi di Kabupaten Kepulauan Sangihe Provinsi Sulawesi Utara (Gambar 1), meliputi: P. Sangihe Besar, P. Nanipah (P. Tinakareng), P. Bukide, P. Kawio, P. Matutuang, dan P. Marore.

Ruang lingkup penelitian dibatasi pada beberapa analisis yang mempunyai kaitan erat dengan tujuan penelitian, yaitu: (1) analisis daya dukung ekonomi dan lingkungan, meliputi: (a) analisis sektor unggulan Kepulauan Sangihe, (b) daya dukung dan depresiasi perikanan tangkap; (2) analisis geopolitik dan apresiasi masyarakat P2K Perbatasan, meliputi: (a) evaluasi kondisi perbatasan, (b) perdagangan lintas batas (border trade area, BTA) Indonesia Filipina, (c) persepsi dan apresiasi masayarakat perbatasan; dan (3) analisis implikasi terhadap kebijakan pengelolaan P2K Perbatasan Kepulauan Sangihe.

\subsection{Data dan Metode Pengumpulan Data}

Data yang dikumpulkan dalam penelitian ini terdiri atas data primer dan data sekunder. Data primer adalah data yang belum tersedia dan diperoleh dengan cara pengambilan langsung di lapangan. Data ini diperoleh melalui survei. Penelitian ini juga banyak memanfaatkan data sekunder yang runtun waktu (time series) yang meliputi data landing (produksi) ikan, input yang digunakan (effort), harga per unit output (harga ikan per kg), indeks harga konsumen (consumers price index), gross domestic regional product (PDRB), persepsi, apresiasi, dan lain-lain Sumber data berasal dari BPS, Dinas Pertanian dan Perkebunan Provinsi/Kabupaten, Dinas Kelautan dan Perikanan Provinsi/Kabupaten, kecamatan, kelurahan/desa, dan tokoh masyarakat. Pengumpulan data dan informasi yang berasal dari stakeholder berupa persepsi dan apresiasi dilakukan melalui wawancara dengan key person.

\subsection{Analisis Data}

Secara umum analisis yang dilakukan meliputi: (1) analisis sektor/komoditas unggulan Kepulauan Sangihe; (2) daya dukung dan depresiasi perikanan tangkap; dan (3) analisis geopolitik, apresiasi masyarakat terhadap pemanfaatan P2K Perbatasan, dan alternatif kebijakan pengelolaan.

\subsubsection{Analisis sektor/komoditas unggulan kepulauan Sangihe}

Metode yang digunakan untuk menentukan sektor / komoditas unggulan Kepulauan Sangihe, meliputi: penentuan struktur ekonomi, partumbuhan ekonomi, metode location quotient (LQ), dan keunggulan komparatif. Untuk mengetahui subsektor atau komoditas yang dapat digunakan sebagai sektor basis di Kabupaten Kepulauan Sangihe, digunakan location quotient dengan persamaan:

$$
L Q=\frac{v_{i t} / v_{t}}{v_{i j} / v_{j}}
$$

dimana

$L Q=$ Locatin Quotient subsektor $\mathrm{di}$ Kabupaten Kepulauan Sangihe;

$v_{i t}=$ Nilai tambah bruto subsektor $i \mathrm{di}$ Kabupaten Kepulauan Sangihe (rupiah);

$v_{t}=$ PDRB di Kabupaten Kepulauan Sangihe (rupiah);

$v_{i j}=$ Nilai tambah bruto subsektor $i$ di Provinsi Sulawesi Utara (rupiah);

$v_{j}=$ PDRB Provinsi Sulawesi Utara (rupiah);

Untuk mengetahui tingkat keunggulan komparatif suatu komoditas yang dapat digunakan metode shift share, dengan formula sebagai berikut:

$$
R_{i j}=N_{i j}+M_{i j}+C_{i j}
$$




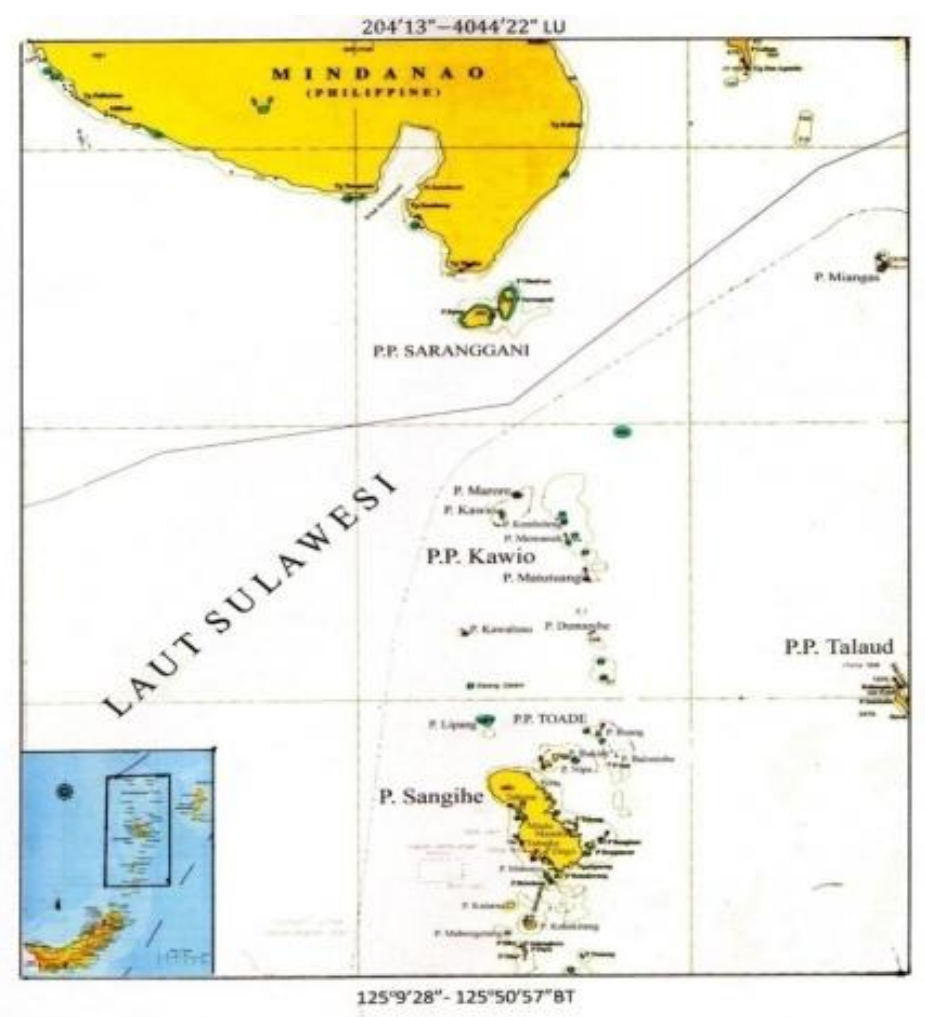

Gambar 1. Lokasi penelitian (Kabupaten Kepulauan Sangihe)

Jika analisis shift share diterapkan dalam analisis dengan menggunakan data Produk Domestik Regional Bruto (PDRB), Kabupaten Kepulauan Sangihe dan PDRB Provinsi Sulawesi Utara sebagai referensinya, maka persamaan tersebut di atas berubah dalam menentukan national growth effect, industry mix, dan regional share, sebagai berikut:

$$
\begin{aligned}
& R_{i j}=E_{i j}^{*}-E_{i j} \ldots \ldots \ldots \\
& N_{i j}=E_{i j}-r_{n} \ldots \ldots \ldots \\
& M_{i j}=E_{i j}\left(r_{i n}-r_{n}\right) . \\
& C_{i j}=E_{i j}\left(r_{i j}-r_{i n}\right) .
\end{aligned}
$$

dimana:

$R_{i j}=$ Perubahan variable sektor $i$ di

Kabupaten Kepulauan Sangihe (rupiah)

$N_{i j}=$ Pertumbuhan nasional sektor $i$ di

Kabupaten Kepulauan Sangihe (rupiah)

$M_{i j}=$ Bauran industri sektor $i$ di

Kabupaten Kepulauan Sangihe (rupiah)
$C_{i j}=$ Keunggulan kompetitif sektor $i$ di Kabupaten Kepulauan Sangihe (rupiah)

$r_{i j}=$ Laju pertumbuhan sektor $i$ di Kabupaten Kepulauan Sangihe (persen)

$r_{i n}=$ Laju pertumbuhan pada sektor $i \mathrm{di}$ Provinsi Sulawesi Utara (persen)

$r_{n}=$ Laju pertumbuhan ekonomi Provinsi Sulawesi Utara (persen)

Untuk menghitung nilai $r_{i j}, r_{i n}$ dan $r_{n}$ dalam penelitian ini digunakan persamaan sebagai berikut:

$$
\begin{aligned}
& r_{i j}=\frac{\left(E_{i j}-E_{i j}\right)}{E_{i j}} . \\
& r_{i n}=\frac{\left(E_{i n}^{*}-E_{i n}\right)}{E_{i n}} \\
& r_{n}=\frac{\left(E_{n}^{*}-E_{n}\right)}{E_{n}} .
\end{aligned}
$$

dimana:

$$
\begin{aligned}
E_{i j}= & \text { PDRB sektor } i \text { di Kabupaten } \\
& \text { Kepulauan Sangihe }
\end{aligned}
$$


$E_{\text {in }}=$ PDRB sektor $i$ di Provinsi Sulawesi Utara

$E_{n}=$ PDRB Provinsi Sulawesi Utara

\subsubsection{Daya dukung dan depresiasi} perikanan tangkap

Untuk menentukan daya dukung dan depresiasi serta pengelolaan optimal perikanan tangkap dilakukan beberapa analisis seperti: standardisasi effort, pendugaan parameter biologi, pendugaan produksi lestari, parameter degradasi dan depresiasi, dan pengelolaan perikanan optimal. Alat tangkap yang digunakan di perairan Kepulauan Sangihe cukup beragam, oleh karena itu dilakukan standardisasi tingkat upaya (effort) dengan menggunakan formula yang dikembangkan oleh King (1985) sebagaimana dikutip oleh Anna (2003), dengan formula sebagai berikut:

dimana

$$
E_{i t}=\varphi_{i t} D_{i t}
$$

$$
\varphi_{i t}=\frac{U_{i t}}{U_{s t d}}
$$

dimana:

$\begin{aligned} E_{i t}= & \text { Tingkat upaya (effort) dari alat } \\ & \text { tangkap } i \text { pada waktu } \mathrm{t} \text { yang }\end{aligned}$ distandardisasi

$D_{i t}=$ Jumlah hari melaut (fishing days) dari alat tangkap $i$ pada waktu $t$.

$\varphi_{i t}=$ Nilai kekuatan menangkap (fishing power) dari alat tangkap $i$ pada waktu $t$.

$U_{i t}=$ Jumlah produksi per alat tangkap (catch per unit effort, CPUE) dari alat tangkap $i$ pada waktu $t$.

$U_{s t d}=\begin{aligned} & \text { Jumlah produksi per alat } \\ & \text { tangkap (catch per unit effort, }\end{aligned}$ CPUE) dari alat tangkap yang dijadikan sebagai basis standar.

Parameter biologi yang diduga meliputi $\mathrm{r}$ adalah pertumbuhan intrinsik (alami), q adalah koefisien kemampuan penangkapan dan $\mathrm{K}$ adalah daya dukung lingkungan (carrying capacity), yang dikembangkan oleh CYP (1992) sebagai berikut:

$$
\ln \left(U_{t+1}\right)=\frac{2 r}{2+r} \ln (q K)+\frac{(2-r)}{(2+r)} \ln \left(U_{t}\right)-\frac{q}{(2+r)}\left(E_{t}+E_{t=1)}\right) .
$$

Untuk memecahkan persamaan (11) tersebut dimulai dengan memisalkan:

$$
\begin{aligned}
& \frac{2 r}{2+r} \ln (q K)=a \\
& \frac{(2-r)}{(2+r)}=b_{1} \\
& \frac{q}{(2+r)}=b_{2}
\end{aligned}
$$

Sehingga persamaan (11) dapat disederhanakan sebagai berikut:

$\ln \left(U_{t+1}\right)=a+b_{1} \ln \left(U_{t}\right)-b_{2}\left(E_{t}+E_{t+1}\right)$

Koefisien penduga $a, b_{1}$ dan $b_{2}$ dapat dihitung dengan menggunakan teknik ordinary least square (OLS). Pemecahan OLS dilakukan dengan menggunakan perangkat komputer dengan metode excel. Oleh karenanya untuk memperoleh nilai unit upaya yang benar, seluruh unit (effort) distandardisasi berdasarkan purse seine base.

Model fungsional untuk menggambarkan stok biomassa, dalam bentuk fungsi Gompertz, sebagaimana persamaan dibawah ini:

Gompertz: $H_{t}=q K E_{t} e^{\left(\frac{-q E}{r}\right)}$

Estimasi parameter $r, K$ dan $q$ untuk persamaan yield-effort dari kedua model di atas (Logistik dan Gompertz) melibatkan teknik non-linear.

Dalam penelitian ini, fungsi degradasi sumber daya perikanan dihitung berdasarkan formula Anna (2003) yang dimodifikasi dari Amman dan Duraiappah (2001), sebagai berikut:

$$
\phi_{t}=\frac{1}{1+e^{\frac{h_{s t}}{h_{a t}}}}
$$

dimana $\phi_{t}$ adalah koefisien atau tingkat degradasi pada periode $t, h_{s t}$ adalah produksi lestari pada periode $t$, dan $h_{a t}$ adalah produksi aktual dalam periode $t$.

Dalam studi ini, perhitungan depresiasi mengunakan dua nilai discount rate yang berbeda, yaitu social discount rate dan nominal discount rate 
Ramsey, dengan asumsi bahwa kurva permintaan bersifat elastis. Untuk perhitungan laju depresiasi pada dasarnya sama dengan laju degradasi, hanya menggunakan parameterparameter ekonomi.

\subsubsection{Analisis geopolitik, apresiasi masyarakat dan kebijakan pengelolaan}

Analisis geopolitik dan apresiasi masyarakat dilakukan secara deskriptif, korelasional dan analisis A'WOT. Analisis korelasional menggunakan data ordinal yang mengukur persepsi masyarakat perbatasan dan pemecahannya menggunakan koefisien korelasi Rank Spearman dan pemecahannya dilakukan melalui program SPSS. Analisis A'WOT adalah gabungan dari analisis SWOT dan AHP, dengan menggunakan persepsi dari setiap key person terhadap permasalahan yang dihadapi. Analisis ini didasarkan pada logika yaitu memaksimalkan kekuatan (strength) dan peluang (opportunities) namun secara bersamaan dapat meminimalkan kelemahan (weaknesses) dan ancaman (threats). Proses hierarki analitik (analytical hierarchy process, AHP) dikembangkan untuk mengorganisasikan informasi dan judgment dalam memilih alternatif disukai (Saaty, 1988). Pemecahannya menggunakan alat analisis Expert Choice versi 11 .

\section{HASIL DAN PEMBAHASAN}

\subsection{Pengembangan Ekonomi Potensial Kepulauan Sangihe}

Hasil pengkajian menunjukkan bahwa struktur ekonomi Kabupaten Kepulauan Sangihe masih tidak bergerak dari sektor pertanian dengan saham sekitar 30\% selang periode tahun 2003 sampai tahun 2007. Pertumbuhan ekonomi dalam kurun waktu tersebut sekitar 4,1\%, dengan pertumbuhan sektor yang tertinggi adalah: listrik, gas, dan air bersih (9,59\%); pertambangan dan penggalian $(7,67 \%)$, sedangkan untuk subsektor diraih oleh subsektor tanaman bahan makanan (7,15\%), perdagangan besar dan eceren $(5,99 \%)$, dan perikanan $(5,35 \%)$.

Perhitungan location quotient (LQ) menunjukkan nilai koefisien LQ > 1 adalah subsektor perkebunan $(2,421)$, peternakan $(1,454)$, perikanan $(1,386)$ perdagangan besar dan eceran $(1,1364)$ dan jasa pemerintahan umum $(1,158)$. Namun dalam perhitungan shift share khususnya keunggulan kompetitif menyatakan bahwa hanya sektor perkebunan dan perikanan yang memiliki nilai positif yaitu perikanan (Rp. 659,96 juta) dan perkebunan (Rp. 7883,88 juta). Dari analisis ini diketahui bahwa pengembangan ekonomi potensial Kabupaten Kepulauan Sangihe adalah tanaman perkebunan dan perikanan (Tabel 1).

Tabel 1 mengisyaratkan bahwa walaupun subsektor perikanan terpilih sebagai salah satu komoditas yang dapat dikembangkan menjadi sandaran ekonomi masyarakat Kepulauan Sangihe tetapi apabila ditinjau dari unsur-unsur pembentuknya relatif masih berada dibawah subsektor perkebunan terutama dari sisi LQ, padahal Kepulauan Sangihe memiliki luas wilayah $11862,97 \mathrm{~km}^{2}$ dengan luas laut sekitar $11126 \mathrm{~km}^{2}$ dan luas daratan hanya $736,97 \mathrm{~km}^{2}$.

\subsection{Daya Dukung dan Depresiasi Perikanan Tangkap}

\subsubsection{Jenis ikan yang dianalisis}

Jenis ikan yang dianalisis dalam penelitian ini adalah: ikan cucut (Charcarias sp.), tuna (Thunnus albacares), ikan cakalang (Katsuwonus pelamis), dan tongkol (Euthynus spp.), ikan laying (Decapterus sp.), dan ikan selar (Selar sp.). Produksi aktual ikan yang dianalisis selama kurun waktu 20 tahun (1988-2007) periode pengamatan disajikan dalam Tabel 2.

Tabel 2 memberikan arahan bahwa produksi ikan yang tertinggi dari jenis yang dianalisis adalah ikan layang dengan rata-rata produksi aktual selama 20 tahun (1988 - 2007) pengamatan sebesar 2551,5 ton/tahun, menyusul ikan tongkol sebanyak 1452 ton/tahun, ikan cakalang sebanyak 626,3 ton/tahun, ikan selar sebesar 546 ton/tahun, ikan cucut sebanyak 478,5 ton/tahun, dan terakhir ikan tuna dengan rata-rata produksi sebanyak 475,2 ton/tahun. Rata-rata produksi aktual ikan yang didaratkan di Kepulauan Sangihe sebesar 8872,1 ton/tahun selama 20 tahun (1988 2007) periode pengamatan, yang apabila dibandingkan dengan jumlah produksi ikan yang dianalisis sebanyak 6129,6 
ton/tahun maka jumlah produksi ikan total produksi ikan yang ada. yang dianalisis mencapai 69 persen dari

Tabel 1. Pertumbuhan ekonomi, LQ, keunggulan kompetetif menurut kegiatan ekonomi Kabupaten Kepulauan Sangihe tahun 2003 - 2007

\begin{tabular}{|l|l|l|l|l|}
\hline No. & \multicolumn{1}{|c|}{ Lapangan usaha } & $\begin{array}{l}\text { Pertumbuhan } \\
\text { sektoral (\%) }\end{array}$ & LQ & \multicolumn{1}{|c|}{$\begin{array}{c}\text { Keunggulan } \\
\text { kompetitif } \\
\text { (000 000 Rp) }\end{array}$} \\
\hline 1 & Pertanian & 3,69 & 1,499 & 8264,59 \\
a. & Tanaman bahan makanan & 7,15 & 0,509 & 875,15 \\
b. & Perkebunan & 2,72 & 2,421 & 7883,88 \\
c. & Peternakan & 1,48 & 1,454 & $-4351,74$ \\
d. & Kehutanan & 3,10 & 0,291 & 95,03 \\
e. & Perikanan & 5,35 & 1,386 & 659,96 \\
2 & Pertambangan dan penggalian & 7,67 & 0,621 & 3844,38 \\
3 & Industri pengolahan & 1,87 & 0,786 & $-3405,91$ \\
4 & Listrik, gas dan air bersih & 9,59 & 0,922 & 210,59 \\
5 & Bangunan & 7,33 & 0,472 & 2256,21 \\
6 & Perdagangan, hotel dan restoran & 3,97 & 1,193 & $-13108,31$ \\
7 & Pengangkutan dan komunikasi & 5,35 & 0,893 & $-2819,89$ \\
8 & Keuangan, persewaan dan jasa & 5,50 & 0,958 & $-493,04$ \\
& perusahaan & 1,60 & 1,007 & $-5989,18$ \\
9 & Jasa-jasa & \multicolumn{3}{|l}{} \\
\hline
\end{tabular}

Tabel 2. Rata-rata produksi aktual ikan yang dianalisis di P2K Perbatasan Sangihe

\begin{tabular}{|c|c|c|c|c|c|c|c|}
\hline \multirow{2}{*}{ Tahun } & \multicolumn{6}{|c|}{ Produksi Jenis Ikan Yang Dianalisis (Ton) } & \multirow{2}{*}{$\begin{array}{c}\text { Total } \\
\text { Analisis }\end{array}$} \\
\hline & Layang & Selar & Cucut & Cakalang & Tuna & Tongkol & \\
\hline 1988 & 1577,8 & 799,4 & 364,2 & 639,3 & 476,6 & 630,1 & 4487,4 \\
\hline 1989 & 1672,8 & 796,8 & 502,4 & 712,4 & 493,1 & 792,3 & 4969,8 \\
\hline 1990 & 1815,2 & 738,0 & 560,4 & 692,6 & 560,3 & 861,9 & 5228,4 \\
\hline 1991 & 2047,9 & 713,3 & 387,5 & 603,8 & 561,6 & 1004,5 & 5318,6 \\
\hline 1992 & 2260,5 & 605,6 & 450,8 & 574,9 & 548,3 & 2113,6 & 6553,7 \\
\hline 1993 & 2321,0 & 690,6 & 482,5 & 664,1 & 534,4 & 1234,7 & 5927,3 \\
\hline 1994 & 1446,4 & 662,2 & 607,6 & 693,7 & 518,8 & 1163,4 & 5092,1 \\
\hline 1995 & 2012,1 & 598,2 & 446,3 & 670,3 & 565,2 & 1245,4 & 5537,5 \\
\hline 1996 & 2002,6 & 554,7 & 574,9 & 729,1 & 561,5 & 2262,3 & 6685,1 \\
\hline 1997 & 1892,3 & 520,1 & 366,5 & 699,8 & 551,8 & 2221,5 & 6252,0 \\
\hline 1998 & 2948,7 & 508,4 & 452,6 & 512,7 & 404,9 & 1997,5 & 6824,8 \\
\hline 1999 & 2706,9 & 503,4 & 398,8 & 712,8 & 401,9 & 1861,9 & 6585,7 \\
\hline 2000 & 3269,8 & 480,3 & 396,2 & 621,4 & 485,6 & 1856,4 & 7109,7 \\
\hline 2001 & 3298,8 & 453,8 & 453,9 & 597,5 & 481,9 & 1449,4 & 6735,3 \\
\hline 2002 & 3314,6 & 434,9 & 498,5 & 623,1 & 457,9 & 1553,3 & 6882,3 \\
\hline 2003 & 3477,1 & 409,6 & 546,5 & 706,3 & 394,6 & 1185,2 & 6719,3 \\
\hline 2004 & 2971,5 & 398,8 & 698,8 & 624,1 & 387,2 & 1534,9 & 6615,3 \\
\hline 2005 & 3095,6 & 386,4 & 654,2 & 545,6 & 460,0 & 1085,6 & 6227,4 \\
\hline 2006 & 3374,4 & 337,4 & 390,7 & 519,8 & 337,3 & 1758,5 & 6718,1 \\
\hline 2007 & 3524,2 & 328,7 & 336,7 & 383,6 & 321,3 & 1227,0 & 6121,5 \\
\hline RATA2 & 2551,5 & 546,0 & 478,5 & 626,3 & 475,2 & 1452,0 & 6129,6 \\
\hline
\end{tabular}

Sumber: Hasil olahan data Dinas Kelautan dan Perikanan (2008) dan BPS (2008)

3.2.2 Pendugaan standardisasi effort

Kalibrasi dilakukan mengingat data mengenai upaya untuk spesies target yang digunakan dalam penelitian ini tidak tersedia. Menurut Fauzi (1998), agregasi upaya merupakan satu-satunya cara pengukuran upaya yang dapat diandalkan pada perikanan multi-species. 
Penelitian ini menggunakan unit trip dari alat tangkap yang digunakan, yang terlebih dahulu standardisasi dari unit upaya (effort). Standardisasi dilakukan menggunakan data produksi dan trip alat tangkap dari tahun 1993 - 2007, dengan menggunakan alat tangkap yang dominan dalam setiap penangkapan (Tabel 3).

Produktivitas terendah adalah penangkapan ikan cucut dan ikan tuna, menyusul ikan cakalang, ikan selar, ikan tongkol dan ikan layang. Perburuan ikan cucut karena selain sirip, minyak hati ikan hiu, juga saat ini daging ikan cucut sudah dibeli oleh pedagang/nelayan Filipina.

\subsubsection{Pendugaan parameter biologi}

Parameter biologi diduga dengan model Clarke Yoshimoto dan Pooley (CYP, 1992). Parameter yang diduga adalah tingkat pertumbuhan intrinsik $(r)$, daya dukung lingkungan (carrying capacity) $(K)$, dan koefisien daya tangkap (q). Sebelum pendugaan parameter biologi dihitung koefisien pendugaan $\alpha, \beta_{1}$, dan $\beta_{2}$ dipecahkan melalui teknik ordinary least square (OLS) dengan bantuan microsoft excel menggunakan persamaan (11) sampai persamaan (15) diperoleh nilai $r$, q dan $\mathrm{K}$ (Table 4). Tabel 4 menunjukkan bahwa ikan layang memiliki daya dukung lingkungan yang tinggi yaitu 14455,728 ton/tahun, menyusul ikan tongkol dengan $\mathrm{K}=$
2280,708 dan ikan cakalang dengan nilai $\mathrm{K}=1092,719$ ton/tahun.

Tabel 4 juga memperlihatkan bahwa pertumbuhan alamiah ikan tongkol sebesar 1,6 persen/tahun, menyusul ikan layang sebesar 1,3 persen/tahun dan ikan tuna sebesar 0,9 persen/tahun, serta yang terendah adalah ikan selar 0,7 persen/tahun. Ikan cucut memiliki pertumbuhan alamiah setinggi 0,8 persen/tahun tetapi kemampuan daya dukung lingkungannya hanya 559,406 ton/tahun.

\subsubsection{Produksi lestari}

Dengan menggunakan nilai $r$, q, dan $\mathrm{K}$ yang disajikan dalam Tabel 4 tersebut di atas dihitung fungsi produksi Gompertz melalui MAPLE versi 13. Dari fungsi produksi tersebut di atas dapat dihitung produksi lestari dengan bantuan microsoft excel, sebagaimana disajikan dalam Tabel 5.

Dari Tabel 5 terlihat bahwa ratarata produksi lestari yang tertinggi adalah ikan layang sebesar 1746,3 ton/tahun dan ikan tongkol sebesar 1073,2 ton/tahun, sedangkan ikan cakalang, selar, tuna, dan cucut masingmasing sebesar 315,6 ton/tahun; 194, 1 ton/tahun; 152 ton/tahun; dan 148,4 ton/tahun. Untuk lebih memberikan gambaran tentang produksi aktual dan produksi lestari dapat dilihat pada Gambar 1, 2, 3, 4, 5, dan Gambar 6.

Tabel 3. Rata-rata effort dan CPUE dari penangkapan jenis ikan yang dianalisis

\begin{tabular}{|c|c|c|}
\hline Jenis ikan & $\begin{array}{c}\text { Rata-rara effort } \\
\text { (trip/tahun) }\end{array}$ & $\begin{array}{c}\text { Rata-rata CPUE } \\
\text { (ton/trip) }\end{array}$ \\
\hline Ikan cucut & 115157 & 0,0015 \\
Ikan tuna & 115157 & 0,0015 \\
Ikan cakalang & 59068 & 0,0070 \\
Ikan tongkol & 65312 & 0,0180 \\
Ikan layang & 63350 & 0,0356 \\
Ikan selar & 55338 & 0,0068 \\
\hline
\end{tabular}

Tabel 4. Nilai parameter biologi jenis ikan yang dianalisis

\begin{tabular}{|c|c|c|c|c|}
\hline \multirow{2}{*}{ No. } & Jenis ikan yang & \multicolumn{3}{|c|}{ Parameter Biologi } \\
\cline { 3 - 5 } dianalisis & r (\%) & Koef tangkap (q) & K (ton) \\
\hline 1 & Ikan Layang & 1,2887 & 0,0000021 & 14455,728 \\
2 & Ikan Tongkol & 1,5991 & 0,0000122 & 2280,708 \\
3 & Ikan Cakalang & 0,8543 & 0,0000189 & 1092,719 \\
4 & Ikan Selar & 0,6809 & 0,0000214 & 976,368 \\
5 & Ikan Cucut & 0,8105 & 0,0000108 & 559,406 \\
6 & Ikan Tuna & 0,8657 & 0,00000452 & 692,310 \\
\hline
\end{tabular}


Tabel 5. Hasil perhitungan produksi lestari bagi ikan yang dianalisis

\begin{tabular}{|c|c|c|c|c|c|c|}
\hline \multirow{2}{*}{ Tahun } & \multicolumn{5}{|c|}{ Produksi Lestari Jenis Ikan Yang Dianalisis (Ton) } \\
\cline { 2 - 7 } & Layang & Selar & Cucut & Cakalang & Tuna & Tongkol \\
\hline 1988 & 990,9 & 215,8 & 166,7 & 298,6 & 270,7 & 646,5 \\
1989 & 1180,0 & 241,3 & 162,8 & 325,7 & 205,7 & 788,4 \\
1990 & 1456,7 & 244,5 & 163,3 & 339,4 & 209,0 & 886,0 \\
1991 & 1538,3 & 244,0 & 164,9 & 343,4 & 222,1 & 957,7 \\
1992 & 1246,3 & 241,9 & 164,7 & 341,3 & 220,6 & 877,9 \\
1993 & 1634,1 & 228,0 & 159,6 & 342,2 & 186,8 & 1007,8 \\
1994 & 2165,0 & 200,9 & 149,3 & 315,2 & 144,4 & 1210,8 \\
1995 & 1579,6 & 207,0 & 152,3 & 335,3 & 155,0 & 1093,8 \\
1996 & 1471,4 & 221,3 & 139,7 & 341,8 & 116,7 & 1013,6 \\
1997 & 2053,2 & 174,9 & 149,1 & 309,0 & 143,7 & 1209,0 \\
1998 & 1647,2 & 199,5 & 142,3 & 332,1 & 123,6 & 1090,0 \\
1999 & 1897,4 & 162,3 & 142,8 & 310,2 & 124,8 & 1201,9 \\
2000 & 2193,7 & 139,6 & 140,8 & 281,8 & 119,4 & 1251,0 \\
2001 & 2606,4 & 84,7 & 139,2 & 222,1 & 115,3 & 1300,5 \\
2002 & 2201,4 & 149,3 & 138,7 & 286,3 & 114,0 & 1243,3 \\
2003 & 1712,8 & 196,8 & 137,5 & 328,8 & 111,1 & 1105,6 \\
2004 & 1595,4 & 207,6 & 138,6 & 338,3 & 113,8 & 1038,5 \\
2005 & 1821,2 & 177,7 & 140,1 & 316,5 & 117,6 & 1146,1 \\
2006 & 2117,4 & 149,6 & 139,7 & 284,8 & 116,6 & 1242,8 \\
2007 & 1817,4 & 196,1 & 136,3 & 318,6 & 108,3 & 1153,1 \\
RATA2 & 1746,3 & 194,1 & 148,4 & 315,6 & 152,0 & 1073,2 \\
\hline
\end{tabular}

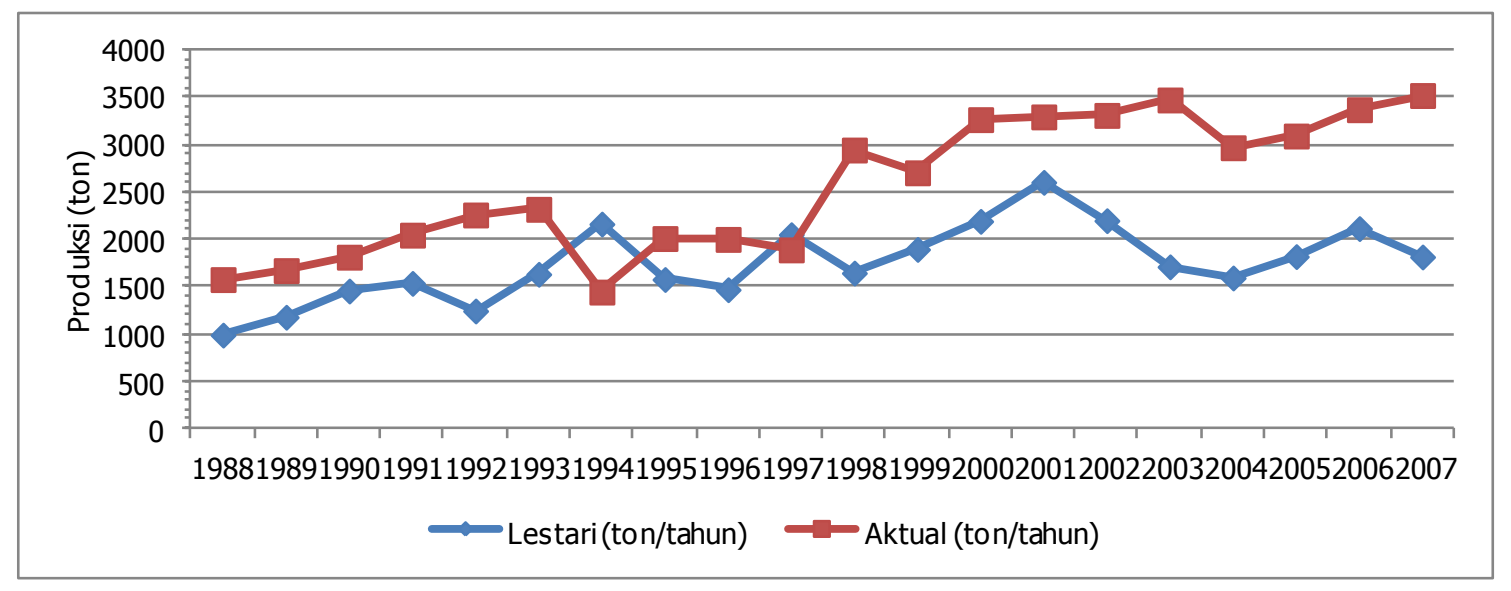

Gambar 2. Grafik produksi aktual dan lestari untuk ikan layang 


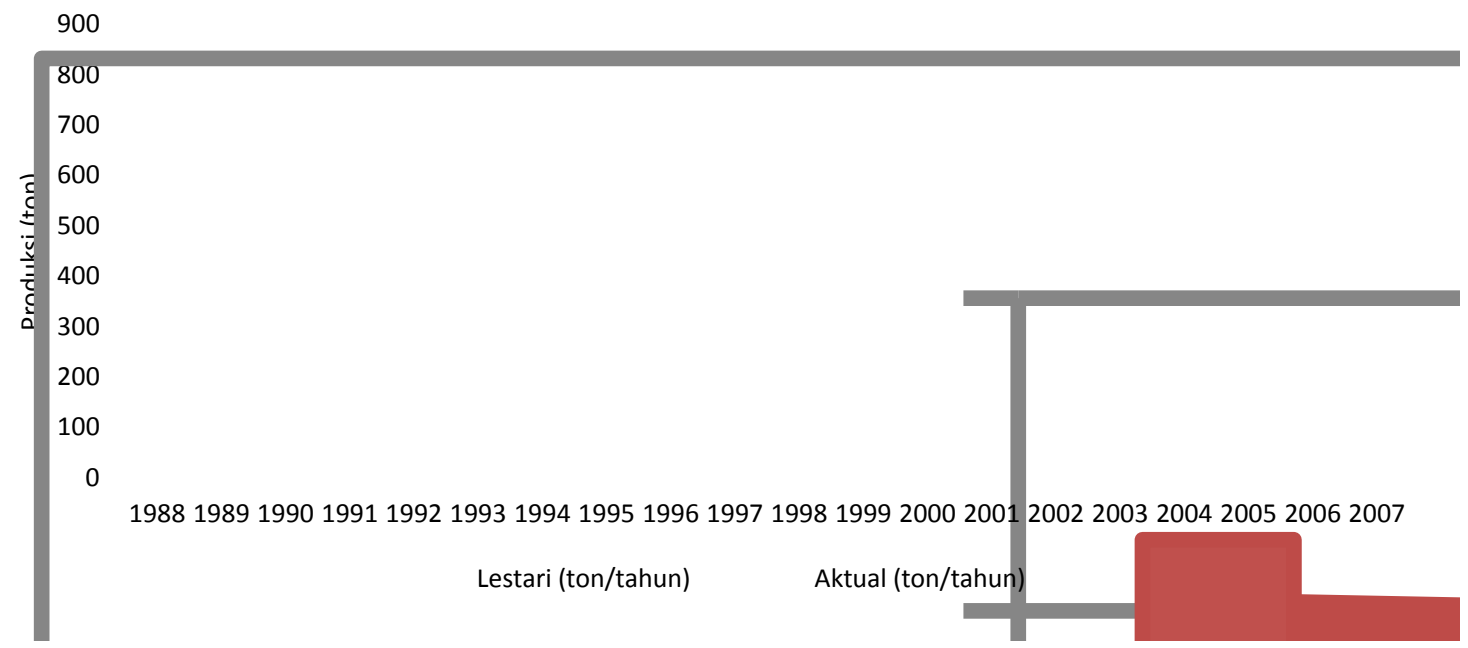

Gambar 3. Grafik produksi aktual dan lestari untuk ikan selar

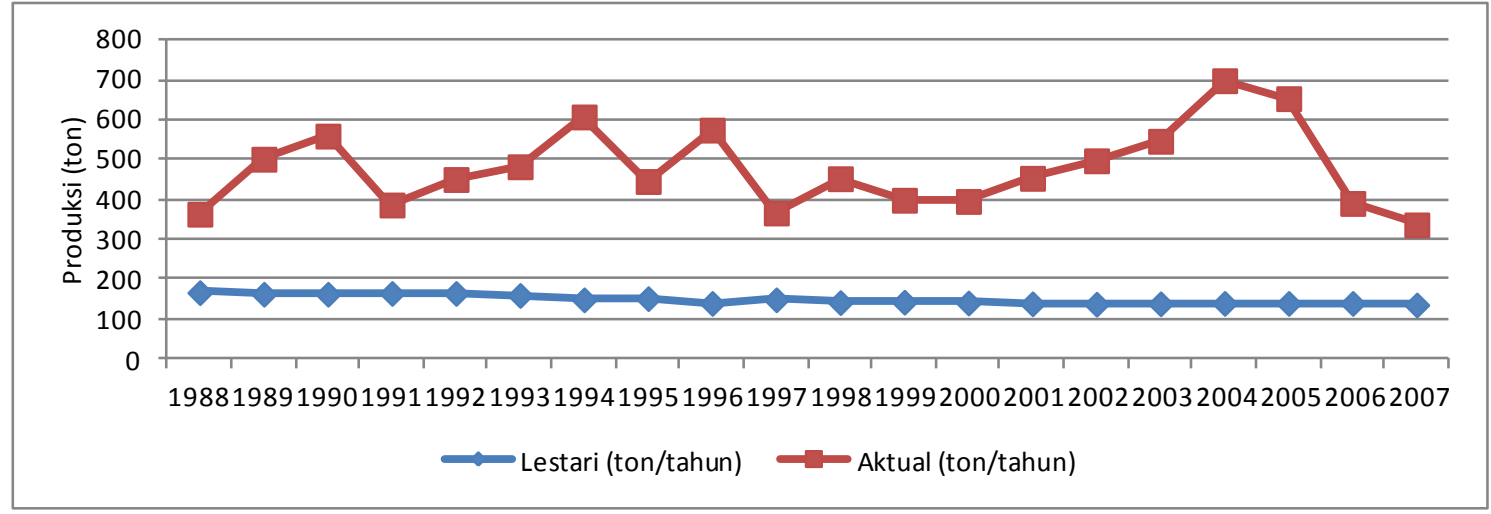

Gambar 4. Grafik produksi aktual dan lestari untuk ikan cucut

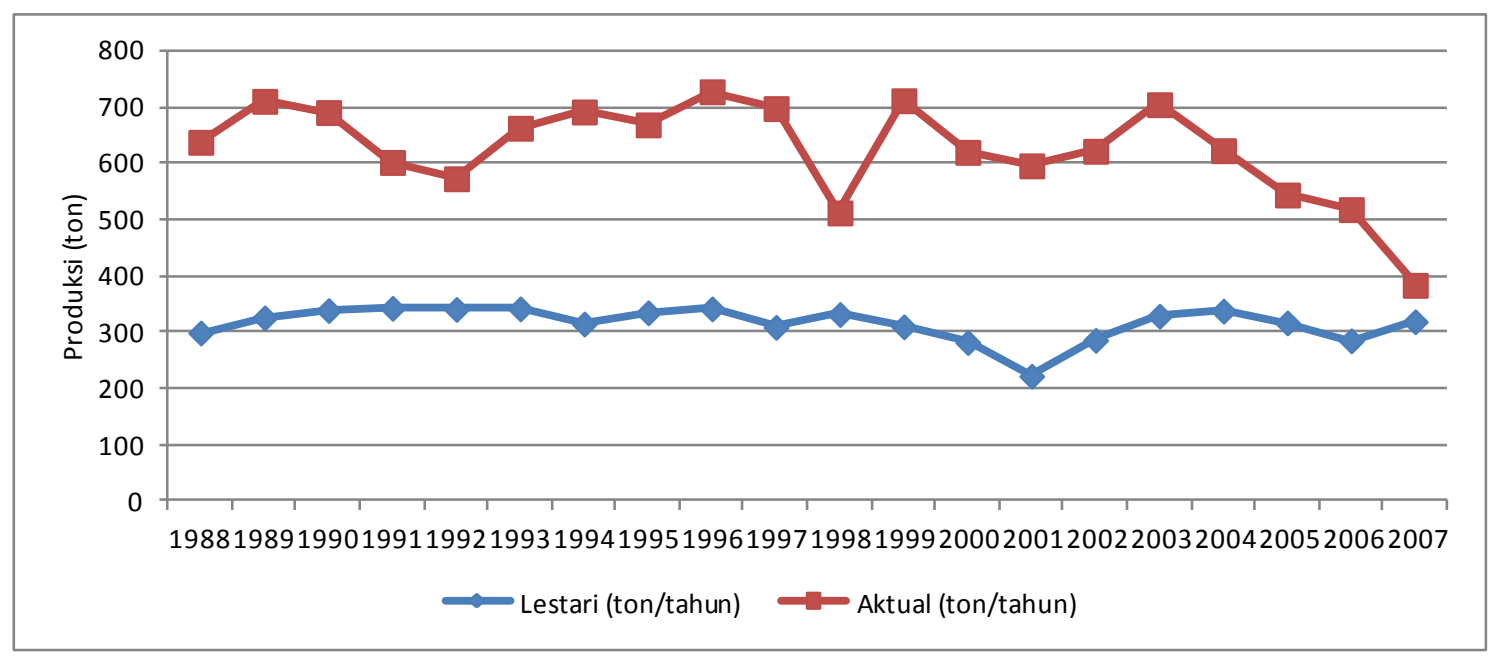

Gambar 5. Grafik produksi aktual dan lestari untuk ikan cakalang 


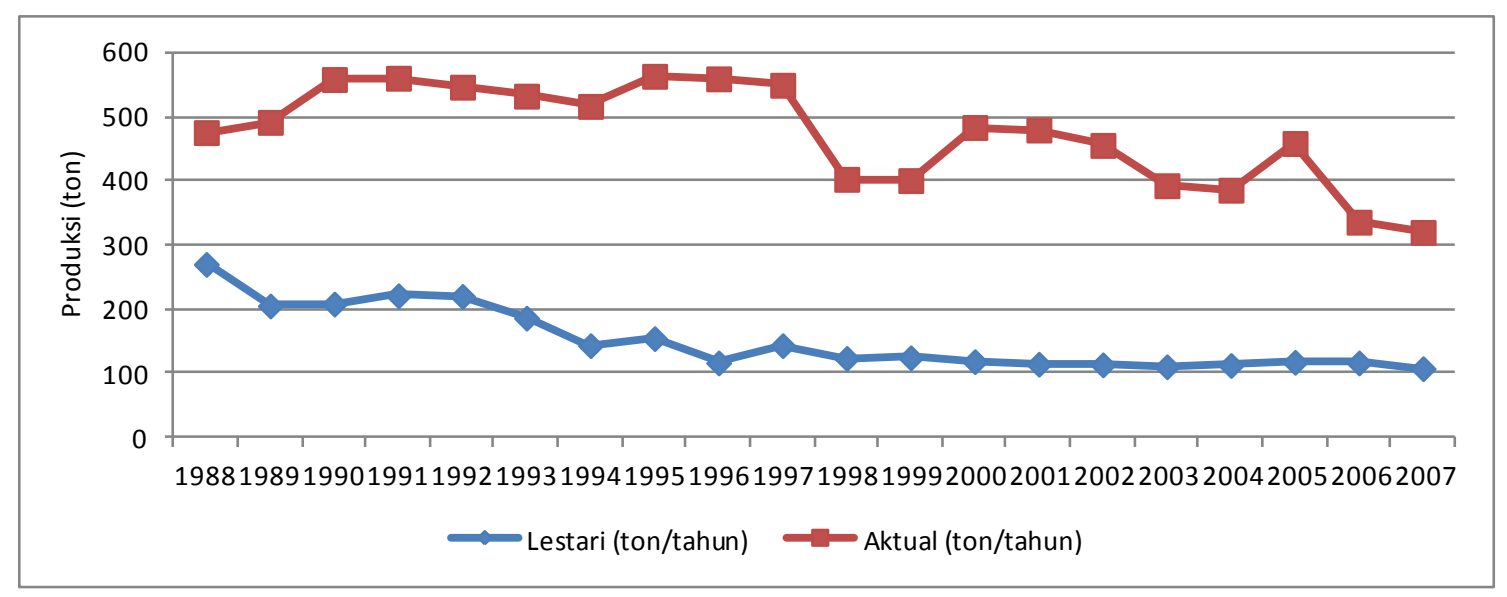

Gambar 6. Grafik produksi aktual dan lestari untuk ikan tuna

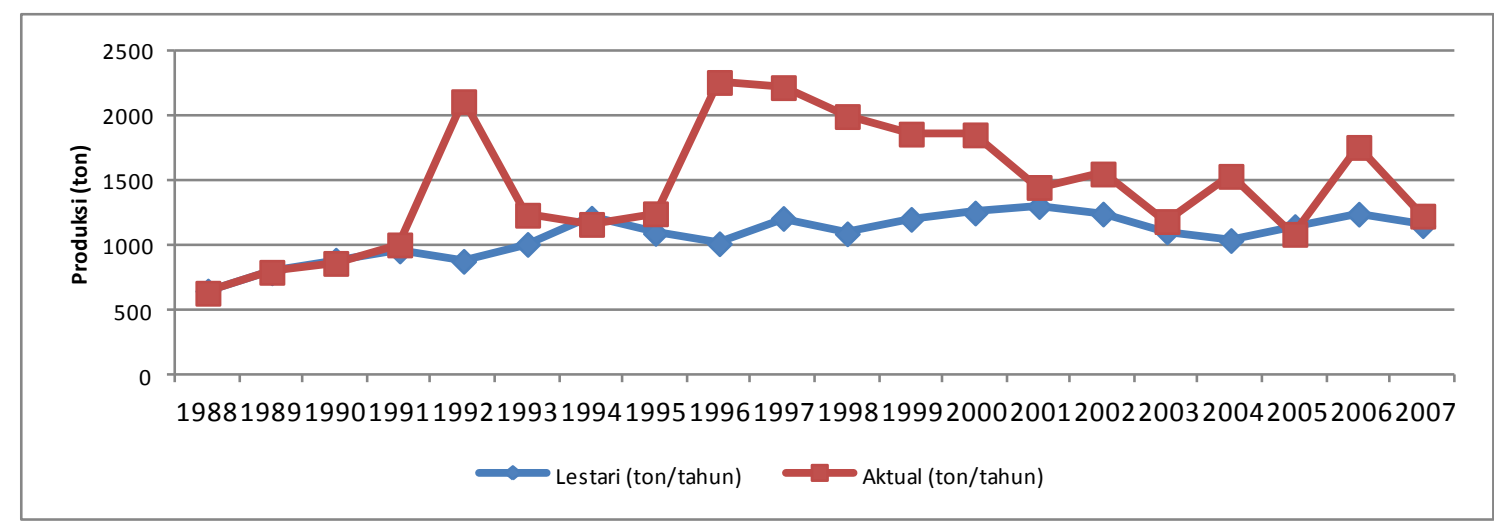

Gambar 7. Grafik produksi aktual dan lestari untuk ikan tongkol

Grafik perkembangan produksi aktual dan produksi lestari yang disajikan dalam Gambar 2 sampai dengan Gambar 7 tersebut di atas memberikan arahan fenomena, yaitu: secara umum posisi produksi lestari berada dibawah garis produksi aktual selama 20 tahun $(1988$ - 2007) periode pengamatan seperti tercermin dalam penangkapan keenam jenis ikan yang dianalisis, hal ini menunjukkan telah terjadi "pengurasan sumber daya ikan" sehingga garis produksi lestari sulit melewati garis produksi aktual. Dari fenomena ini, dapat ditarik kesimpulan bahwa arah kebijakan harus dilakukan adalah menekan terjadinya penangkapan ikan yang melebihi produksi lestari.

\subsubsection{Degradasi sumber daya perikanan}

Eksploitasi sumber daya ikan (SDI) yang melebihi titik keseimbangan ini akan menyebabkan terjadinya degradasi SDI itu sendiri. Degradasi SDI diartikan sebagai penurunan kualitas atau kuantitas sumber daya ikan atau berkurangnya kemampuan alami sumber daya ikan untuk beregenerasi sesuai dengan kapasitas produksinya. Tingkat degradasi SDI akan memberikan suatu gambaran yang menunjukkan adanya gejala penurunan potensi dari SDI itu sendiri. Analisis koefisien degradasi dilakukan untuk semua jenis ikan yang dianalisis dalam penelitian, dengan hasil perhitungan degradasi baik untuk lestari maupun aktual, sebagaimana disajikan dalam Gambar 7.

Dalam Gambar 7 terlihat bahwa degradasi yang terjadi cukup "parah" terutama bagi penangkapan ikan selar dan ikan cucut selama 20 tahun (1988 2007) periode pengamatan yang terdegradasi $44 \%$ untuk jenis ikan selar dan $42 \%$ untuk jenis ikan cucut. Jenis ikan lainnya juga harus diwaspadai karena telah terjadi degradasi diatas $35 \%$, seperti ikan tuna degradasi terjadi sekitar 39\% dan ikan cakalang sekiatr $37 \%$. Nilai degradasi yang rendah terjadi 
pada jenis ikan layang sekitar 33\% dan ikan tongkol sebesar 31\%.

\subsubsection{Depresiasi sumber daya perikanan}

Untuk menilai depresiasi SDI digunakan metode present value. Artinya bahwa seluruh rente yang akan datang (future value of rent) yang diharapkan dihasilkan dari SDI dihitung dengan nilai masa sekarang (present value). Perhitungan depresiasi dalam penelitian ini menggunakan dua nilai discount rate yang berbeda yaitu market discount rate $15 \%$ dan real discount rate Kula (4,94\%). Nilai real discount rate Kula memberikan indikasi bahwa tingkat resiko berusaha akan sangat besar di wilayah perairan Kepulauan Sangihe dan juga memberikan pedoman pengelolaan bahwa perlakuan khusus perlu diterapkan dalam pengelolaan perikanan di Kepulauan Sangihe.

Berdasarkan formula tersebut di atas dan data biofisik serta data ekonomi yang telah dikaji sebelumnya, maka dihitung nilai depresiasi jenis ikan yang dianalisis dalam penelitian. Perhitungan depresiasi dengan menggunakan metode present value maka depresiasi yang terjadi sebesar Rp. 117,77 miliar pada discount rate $15 \%$ dan pada discount rate 4,94\% depresiasi yang terjadi sebesar Rp. 417,08 miliar. Penerimaan seharusnya sebesar Rp. 242,67 miliar pada discount rate $15 \%$ tetapi karena depresiasi maka penerimaannya hanya Rp. 124,91 miliar, demikian pula pada discount rate $4.94 \%$ penerimaan seharusnya Rp. 737,09 miliar tetapi karena terdepresiasi sisanya hanya Rp. 417,08 miliar (Tabel 6).

Tabel 6 tersebut juga memberikan arahan bahwa nilai perubahan rente ekonomi (depresiasi) yang tertinggi terjadi pada penangkapan ikan layang dan penangkapan ikan tongkol, karena kedua jenis ikan ini merupakan jenis ikan yang sangat dominan dalam jumlah penangkapan di Kepulauan Sangihe, menyusul penangkapan ikan tuna, cucut, cakalang, julung-julung dan penangkapan ikan selar.

Perubahan rente ekonomi sumber daya ikan layang yang dijadikan contoh perhitungan dapat diuraikan sebagai berikut. Selama 20 tahun (1988-2007) periode pengamatan dalam penangkapan ikan layang telah terjadi depresiasi dengan kisaran Rp. 549,21 juta sampai dengan Rp. 7,21 miliar, dengan total depresiasi sekitar Rp. 27,92 miliar. Jumlah rente ekonomi yang seharusnya diterima dari penangkapan ikan layang sekitar Rp. 43,15 miliar pada market discount rate 15\% tetapi karena terjadi depresiasi maka rente ekonomi menjadi Rp. 15,23 miliar. Depresiasi terjadi pada sekitar 12 tahun dari 20 tahun (19932007) pengamatan, yaitu pada tahun 1989, 1990, 1991, 1993, 1994, 1997, 1999, 2000, 2001, 2005, 2006 dan tahun 2007 (Tabel 7).

Selanjutnya perhitungan rente pada real discount rate yang lebih konservatif dari Kula 4,94\% menghasilkan nilai rente sebesar Rp. 131,25 miliar, tetapi depresiasi yang terjadi sebesar Rp. 85,01 miliar menyebabkan berkurangnya rente menjadi Rp. 46,24 miliar selama 20 tahun (1988 - 2007) periode pengamatan. Perhitungan rente sumber daya perikanan layang dengan menggunakan discount rate yang lebih konservatif dari Kula (4,94\%), depresiasi ikan layang terjadi pada tahun yang sama dengan market discount rate $15 \%$, dengan kisaran depresiasi Rp. 1,67 miliar sampai Rp. 21,89 miliar.

Depresiasi sumber daya perikanan layang mengalami pola atau perilaku yang counter cyclical antara effort dan produksi aktual. Pada saat effort terjadi penurunan/peningkatan, produksi aktual tidak menunjukkan proporsi yang seimbang atau sama dalam proses penurunan/peningkatan sesuai dengan pola effort yang ada, malahan bisa terjadi sebaliknya, yaitu effort mengalami penurunan, produksi aktual justru meningkat. Sebagai contoh ketika effort ikan layang naik dari sekitar 58965 trip ke 69062 trip dari tahun 1998 ke 1999, produksi aktual justru turun dari 2948,7 ton ke 2706,9 ton. Pola atau perilaku yang counter cyclical ini menyebabkan penurunan pada tangkap lestari (sustainable yield) sehingga menyebabkan terjadinya depresiasi rente pada sumber daya perikanan layang. Implikasinya terhadap kebijakan adalah bahwa untuk meningkatkan nilai stok sumber daya perikanan layang, kebijakan untuk menurunkan level input (effort) adalah pilihan yang tepat. Pola depresiasi rente sumber daya terhadap present value dari rente sumber daya ikan layang tertera dalam Gambar 8. 


\subsubsection{Pengelolaan sumber daya perikanan yang optimal}

Sumber daya perikanan merupakan aset kapital yang dalam pengelolaannya harus dikelola secara optimal juga memerlukan kapital. Pada pendekatan kapital, biaya korbanan (opportunity cost) untuk mengelola SDI pada saat ini dihitung melalui rente ekonomi optimal (optimal rent) yang seharusnya diperoleh dari SDI apabila dikelola secara optimal. Dalam kondisi aktual, jarang sekali terjadi pemanfaatan sumber daya perikanan pada penang- kapan maupun effort yang optimal, padahal dengan melakukan pemanfaatan pada tingkat optimal inilah maka perikanan tangkap akan lestari. Analisis dilakukan menggunakan market discount rate $15 \%$ dan real discount rate Kula $4,94 \%$ dengan pemecahan analitik melalui program MAPLE versi 13 yang menghasilkan nilai optimal biomas $\left(x^{*}\right)$, produksi $\left(h^{*}\right)$ dan input optimal $\left(E^{*}\right)$ untuk ikan yang dianalisis dalam penelitian ini disajikan dalam Tabel 8.

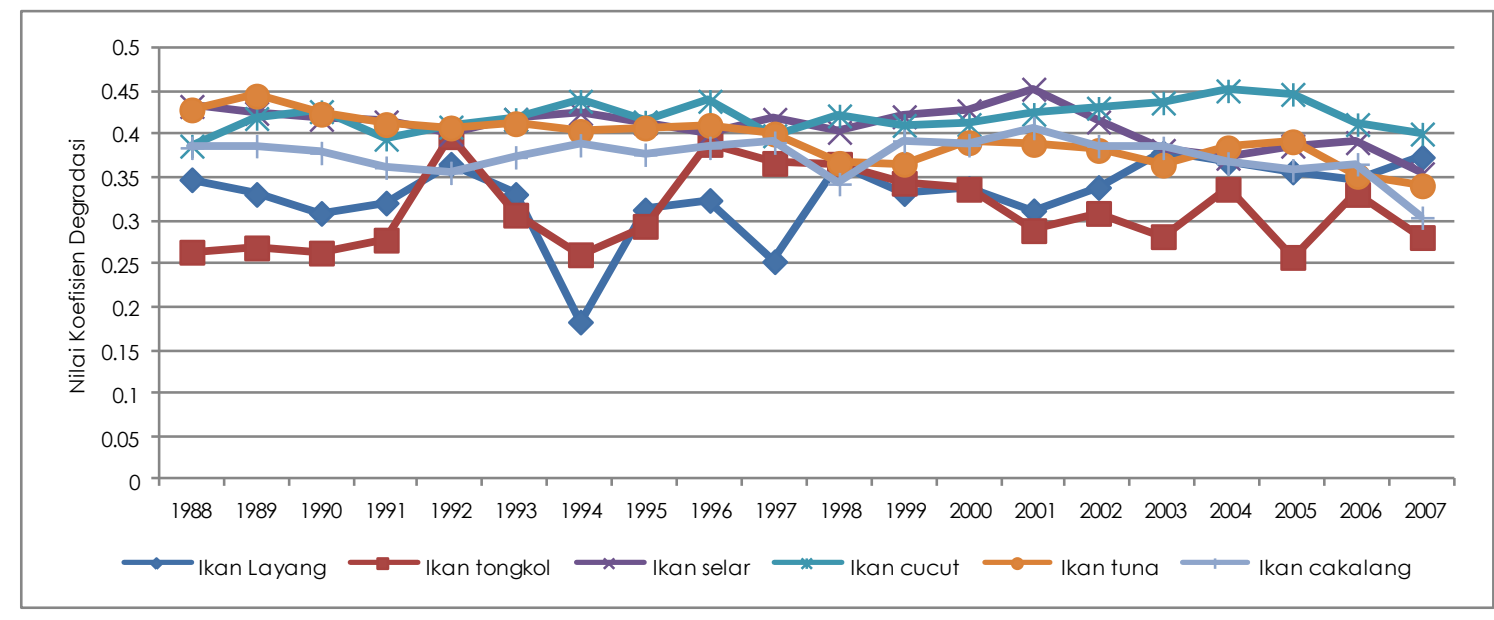

Gambar 8. Grafik degradasi ikan yang dianalisis

Tabel 6. Perhitungan rente diterima, depresiasi dan jumlah rente sebenarnya

\begin{tabular}{|l|l|l|l|l|}
\hline Jenis Ikan & $\begin{array}{c}\text { Discount } \\
\text { Rate }\end{array}$ & $\begin{array}{c}\text { Jumlah } \\
\text { Seharusnya } \\
\text { Diterima (Rp/Juta) }\end{array}$ & $\begin{array}{c}\text { Depresiasi Yang } \\
\text { Terjadi } \\
\text { (Rp/Juta) }\end{array}$ & $\begin{array}{c}\text { Surplus Setelah } \\
\text { Depresiasi } \\
\text { (Rp/Juta) }\end{array}$ \\
\hline Ikan Layang & $15 \%$ & 43150,69 & 27919,26 & 15231,42 \\
& $4,94 \%$ & 131260,84 & 85011,58 & 46249,26 \\
Ikan Selar & $15 \%$ & 38041,08 & 19289,36 & 18751,72 \\
& $4,94 \%$ & 115509,36 & 58570,93 & 56938,43 \\
Ikan Cucut & $15 \%$ & 16391,99 & 4904,79 & 11487,20 \\
& $4,94 \%$ & 49773,24 & 14893,08 & 34880,16 \\
Ikan & $15 \%$ & 38254,21 & 18442,66 & 19811,55 \\
Cakalang & $4,94 \%$ & 116156,50 & 43924,79 & 72231,70 \\
Ikan Tuna & $15 \%$ & 37085,60 & 9101,29 & 27984,31 \\
& $4,94 \%$ & 112608,08 & 27635,49 & 84972,60 \\
Ikan Tongkol & $15 \%$ & 69749,57 & 38109,99 & 31639,58 \\
& $4,94 \%$ & 211790,20 & 115718,59 & 96071,61 \\
\hline Jumlah & $15 \%$ & 242673,14 & 117767,35 & 124905,78 \\
& $4,94 \%$ & 737098,22 & 345754,46 & 391343,76 \\
\hline
\end{tabular}


Tabel 7. Perubahan rente ekonomi (depresiasi) sumber daya ikan layang di perairan Kepulauan Sangihe

\begin{tabular}{|c|c|c|c|c|c|c|c|c|c|}
\hline \multirow{2}{*}{ Tahun } & \multirow{2}{*}{$\begin{array}{l}\text { Sus Rev } \\
\text { (Rp.Juta) }\end{array}$} & \multirow{2}{*}{$\begin{array}{c}\text { TC } \\
\text { (Rp. } \\
\text { Juta) }\end{array}$} & \multirow{2}{*}{$\begin{array}{c}\text { Sus Rent } \\
\text { (Rp. } \\
\text { Juta) }\end{array}$} & \multicolumn{2}{|c|}{ Discount rate } & \multirow{2}{*}{$\begin{array}{c}\text { PV Ra } \\
\text { (Rp.Juta) }\end{array}$} & \multirow{2}{*}{ A PV.Ra } & \multirow{2}{*}{$\begin{array}{c}\text { PV Rb } \\
\text { (Rp.Juta) }\end{array}$} & \multirow{2}{*}{$\Delta$ PV.Rb } \\
\hline & & & & Market & Real & & & & \\
\hline 1988 & 2459,14 & 1684,43 & 774,71 & 0,15 & 0,0494 & 5164,73 & 5164,73 & 15682,38 & 15682,38 \\
\hline 1989 & 2942,47 & 2038,79 & 903,67 & 0,15 & 0,0494 & 6024,49 & $-859,76$ & 18292,98 & $-2610,60$ \\
\hline 1990 & 3918,95 & 2762,84 & 1156,11 & 0,15 & 0,0494 & 7707,42 & $-1682,94$ & 23403,11 & $-5110,13$ \\
\hline 1991 & 4554,90 & 3228,00 & 1326,89 & 0,15 & 0,0494 & 8845,95 & $-1138,52$ & 26860,16 & $-3457,05$ \\
\hline 1992 & 3975,10 & 2765,58 & 1209,52 & 0,15 & 0,0494 & 8063,47 & 782,48 & 24484,21 & 2375,95 \\
\hline 1993 & 5808,19 & 4141,87 & 1666,32 & 0,15 & 0,0494 & 11108,79 & $-3045,32$ & 33731,14 & $-9246,93$ \\
\hline 1994 & 7978,57 & 5898,27 & 2080,30 & 0,15 & 0,0494 & 13868,66 & $-2759,87$ & 42111,32 & $-8380,18$ \\
\hline 1995 & 6291,29 & 4470,50 & 1820,78 & 0,15 & 0,0494 & 12138,54 & 1730,12 & 36857,92 & 5253,41 \\
\hline 1996 & 6144,14 & 4335,64 & 1808,50 & 0,15 & 0,0494 & 12056,70 & 81,84 & 36609,41 & 248,51 \\
\hline 1997 & 10843,78 & 7953,94 & 2889,84 & 0,15 & 0,0494 & 19265,60 & $-7208,91$ & 58498,79 & $-21889,39$ \\
\hline 1998 & 8739,83 & 6237,81 & 2502,02 & 0,15 & 0,0494 & 16680,14 & 2585,46 & 50648,20 & 7850,59 \\
\hline 1999 & 10386,19 & 7537,38 & 2848,81 & 0,15 & 0,0494 & 18992,05 & $-2311,91$ & 57668,17 & $-7019,97$ \\
\hline 2000 & 12318,31 & 9124,96 & 3193,35 & 0,15 & 0,0494 & 21288,98 & $-2296,92$ & 64642,64 & $-6974,47$ \\
\hline 2001 & 15206,46 & 11609,68 & 3596,77 & 0,15 & 0,0494 & 23978,50 & $-2689,52$ & 72809,21 & $-8166,57$ \\
\hline 2002 & 13485,02 & 9994,62 & 3490,40 & 0,15 & 0,0494 & 23269,31 & 709,19 & 70655,80 & 2153,40 \\
\hline 2003 & 10589,15 & 7590,35 & 2998,80 & 0,15 & 0,0494 & 19992,01 & 3277,30 & 60704,49 & 9951,31 \\
\hline 2004 & 9919,97 & 7056,22 & 2863,76 & 0,15 & 0,0494 & 19091,71 & 900,30 & 57970,78 & 2733,71 \\
\hline 2005 & 11329,98 & 8180,19 & 3149,78 & 0,15 & 0,0494 & 20998,56 & $-1906,85$ & 63760,81 & $-5790,03$ \\
\hline 2006 & 13182,98 & 9713,13 & 3469,84 & 0,15 & 0,0494 & 23132,30 & $-2133,74$ & 70239,77 & $-6478,97$ \\
\hline 2007 & 12769,01 & 9216,79 & 3552,23 & 0,15 & 0,0494 & 23681,51 & $-549,21$ & 71907,41 & $-1667,64$ \\
\hline
\end{tabular}

Keterangan

Sus Rev : penerimaan lestari (sustainable revenue)

TC : total cost

Sus Rent : rente lestari (sustainable rent)

PVRa : present value sustainable rent dengan $\delta$ market $15 \%$

$\mathrm{PVRb} \quad$ : present value sustainable rent dengan $\delta$ real $4.94 \%$

$\triangle \mathrm{PVRa} \quad$ : perubahan present value sustainable rent dengan $\delta$ market $15 \%$

$\triangle \mathrm{PVRb} \quad$ : perubahan present value sustainable rent dengan $\delta$ real $4.94 \%$

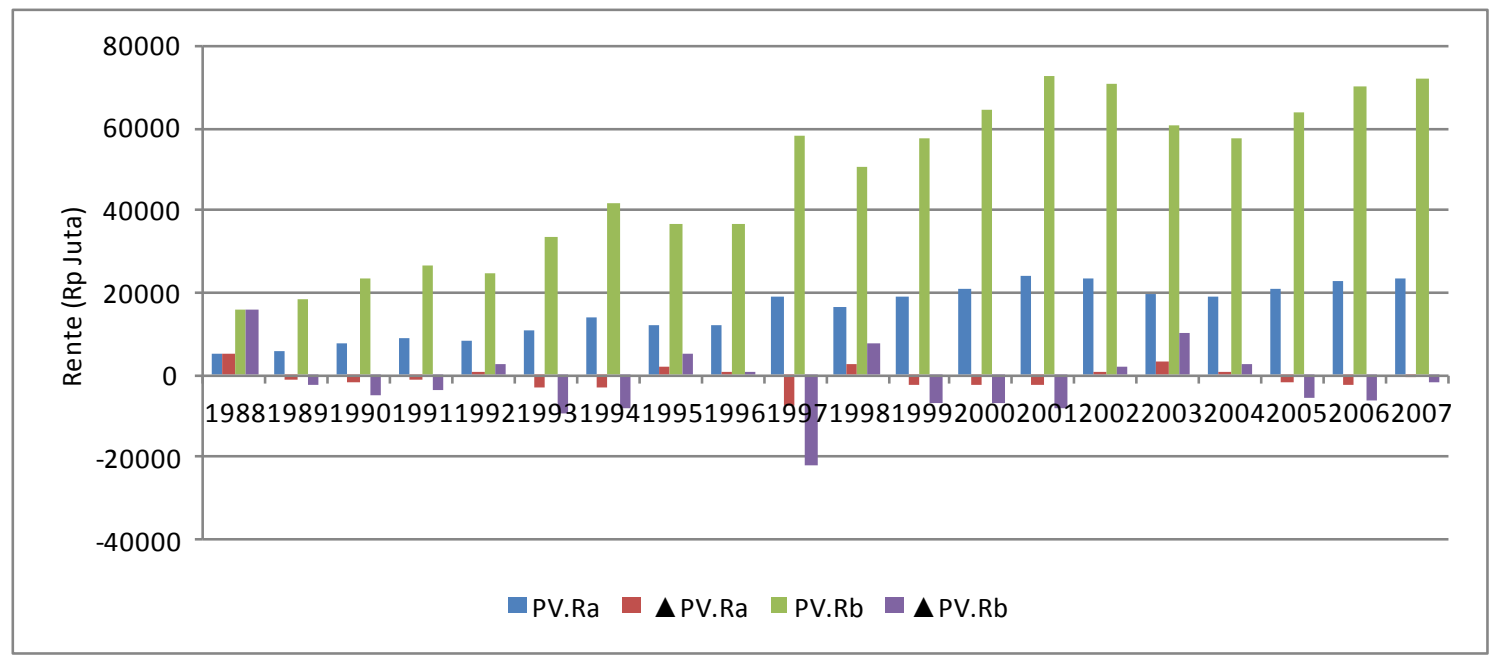

Gambar 9. Present value rente dan depresiasi sumber daya ikan layang 
Tabel 8. Nilai optimal biomassa, hasil tangkapan dan effort dengan $\delta$ yang berbeda untuk ikan yang dianalisis dalam penelitian

\begin{tabular}{|l|l|l|l|l|l|l|}
\hline \multirow{2}{*}{ Jenis Ikan } & \multicolumn{3}{|c|}{ Kelola Optimal 15\% } & \multicolumn{3}{c|}{ Kelola Optimal 4.94\% } \\
\cline { 2 - 7 } & $\mathbf{x}^{*}$ (ton) & $\mathbf{h}^{*}$ (ton) & $\mathbf{E}^{*}$ (trip) & $\mathbf{x}^{*}$ (ton) & $\mathbf{h}^{*}$ (ton) & $\mathbf{E}^{*}$ (trip) \\
\hline Ikan layang & 13004,1 & 1771,9 & 63972 & 13150,9 & 1601,8 & 57182 \\
Ikan selar & 319,8 & 244,6 & 35508 & 360,8 & 243,1 & 31667 \\
Ikan cucut & 241,5 & 164,4 & 63104 & 257,1 & 161,9 & 58391 \\
Ikan cakalang & 473,3 & 338,3 & 37822 & 503,2 & 333,4 & 35056 \\
Ikan tuna & 451,5 & 167,1 & 81867 & 460,5 & 162,5 & 78075 \\
Ikan tongkol & 1856,2 & 611,2 & 26902 & 1886,5 & 572,4 & 24788 \\
\hline
\end{tabular}

Hasil penelitian untuk seluruh jenis ikan dalam penelitian ini menunjukkan bahwa pada real discount rate dari Kula $(4,94 \%)$ memerlukan input yang lebih rendah untuk menghasilkan optimal biomass dan optimal yield. Namun sebaliknya pada market discount rate $15 \%$ diperlukan input level yang tinggi tetapi menghasilkan optimal biomass yang lebih rendah dari real discount rate.

Secara umum dapat dikatakan bahwa pada tingkat discount rate yang lebih rendah (konservatif) dapat memnghasilkan optimal biomass jauh lebih tinggi dibandingkan dengan menggunakan discount rate yang lebih besar (ekstraktif). Pada tingkat effort optimal yang rendah, maka eksploitasi sumber daya ikan juga akan rendah, dengan demikian penambahan biomassa akan terjadi dan mendorong terjadinya penangkapan yang lebih produktif serta mendorong meningkatkan optimal yield dalam suatu proses penangkapan. Artinya semakin tinggi discount rate akan mendorong tingkat eksploitasi sumber daya lebih ekstraktif sehingga akan mempertinggi tekanan terhadap sumber daya pada gilirannya akan mempercepat laju degradasi yang berdampat kepada kepunahan. Hasil ini sejalan dengan pernyataan beberapa peneliti terdahulu yaitu nilai discount rate yang lebih tinggi akan menyebabkan peningkatan laju optimal dan eksploitasi sumber daya terbarukan, dengan demikian kemungkinan akan terjadi kepunahan semakin besar (Clark, 1971 dikutip oleh Hanesson 1987; Clark, 1996; Anna, 2003).

Untuk sumber daya perikanan yang memiliki fungsi pertumbuhan berbentuk cembung (concave), discount rate yang lebih tinggi akan menyebabkan stock biomass menjadi lebih sedikit (Efrizal, 2005). Selain itu, discount rate juga mengekspresikan opportunity cost dari kapital untuk diinvestasikan pada peralatan produksi. Semakin tinggi discount rate akan menyebabkan biaya produksi (production cost) menjadi lebih tinggi (Anna, 2003; Efrizal, 2005). Implikasinya akan mendorong terjadinya cara-cara pemanfaatan sumber daya ikan yang tidak ramah lingkungan. Kondisi ini dapat diperparah dengan keterbatasan pasar bagi nelayan di Kepulauan Sangihe, sehingga pilihan untuk melakukan upaya kearah fishing ground lebih jauh dari wilayah pesisir semakin dipertimbangkan oleh mereka. Dengan mengetahui nilai optimal ketiga variabel tersebut, maka akan dapat dibandingkan kondisi pengelolaan sumber daya ikan yang dianalisis dalam penelitian pada kondisi aktual, lestari maupun optimal. Perbandingan dari sisi produksi antara ketiga kondisi tersebut dengan menggunakan tingkat nilai market discount rate dan real disount rate untuk ikan yang dianalisis dalam penelitian ini secara berturut-turut pada Gambar 10, 11, 12, 13, 14, dan Gambar 15. 


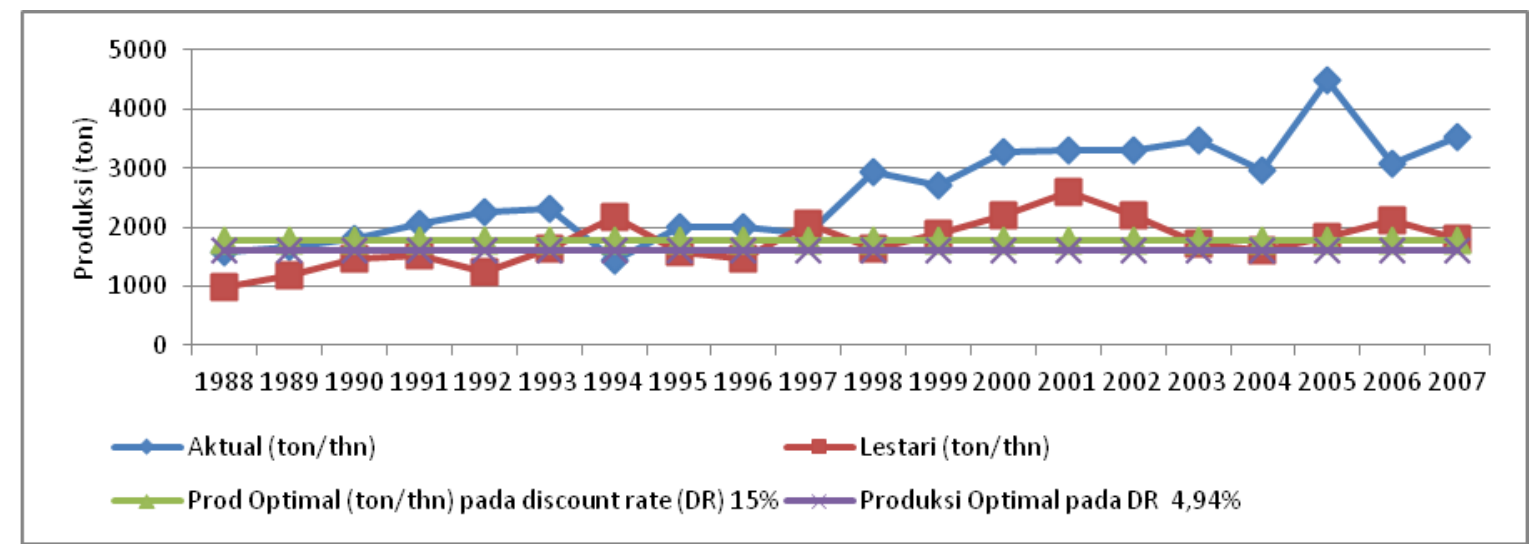

Gambar 10. Perbandingan produksi aktual, lestari dan produksi optimal ikan layang pada market discount rate $15 \%$ dan real discount rate $4,94 \%$

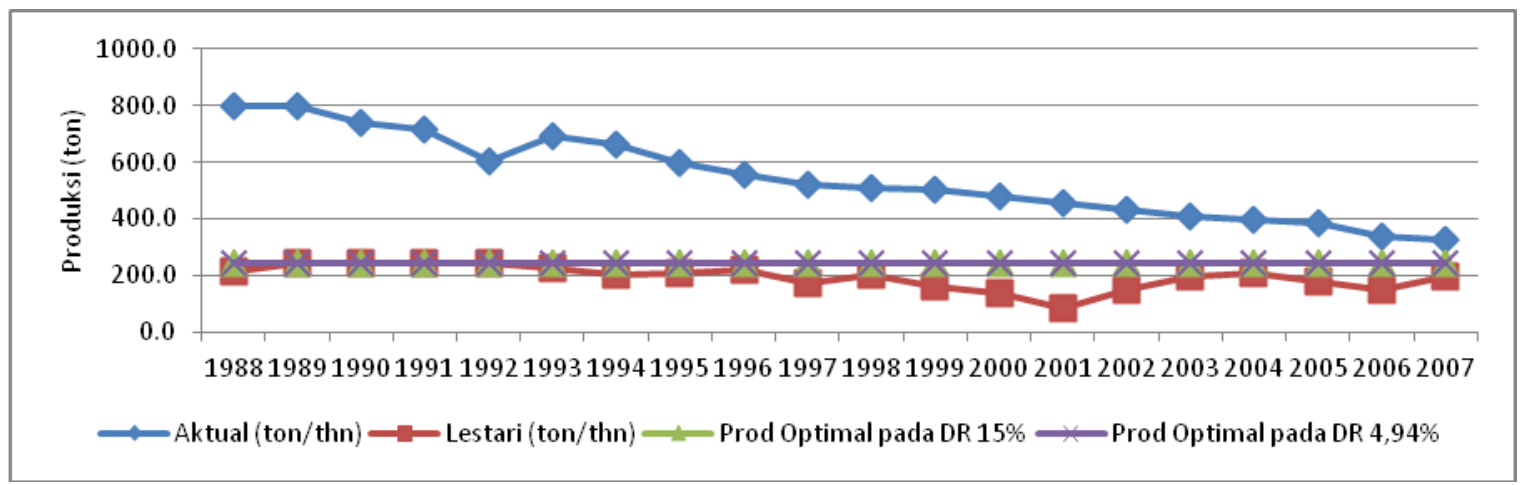

Gambar 11. Perbandingan produksi aktual, lestari dan produksi optimal ikan selar pada market discount rate $15 \%$ dan real discount rate $4,94 \%$

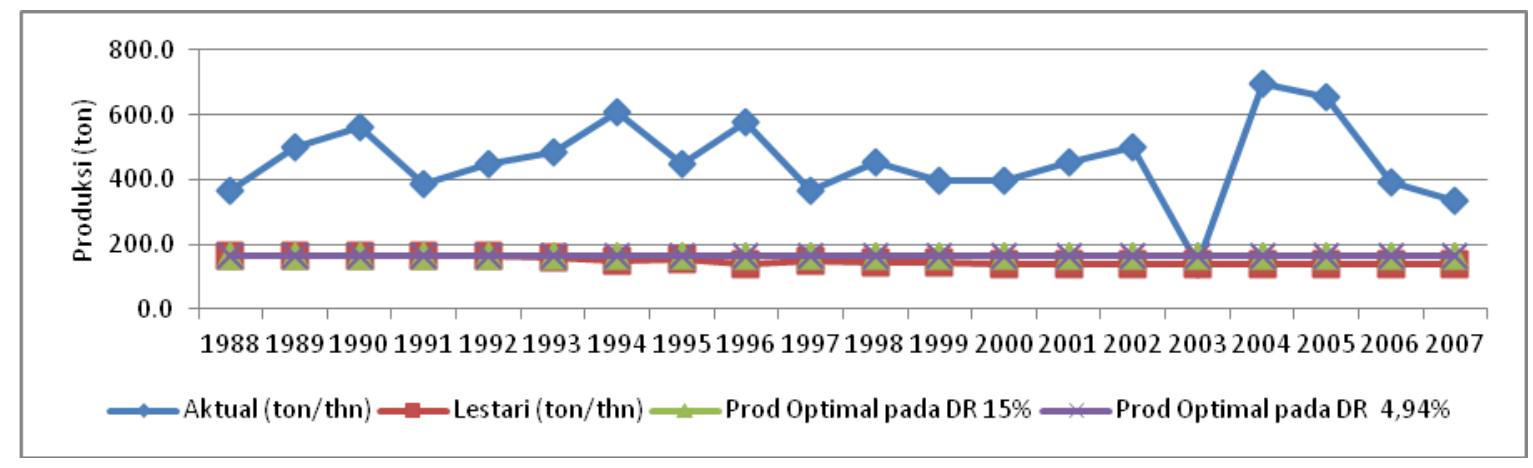

Gambar 12. Perbandingan produksi aktual, lestari dan produksi optimal ikan cucut pada market discount rate $15 \%$ dan real discount rate $4,94 \%$ 


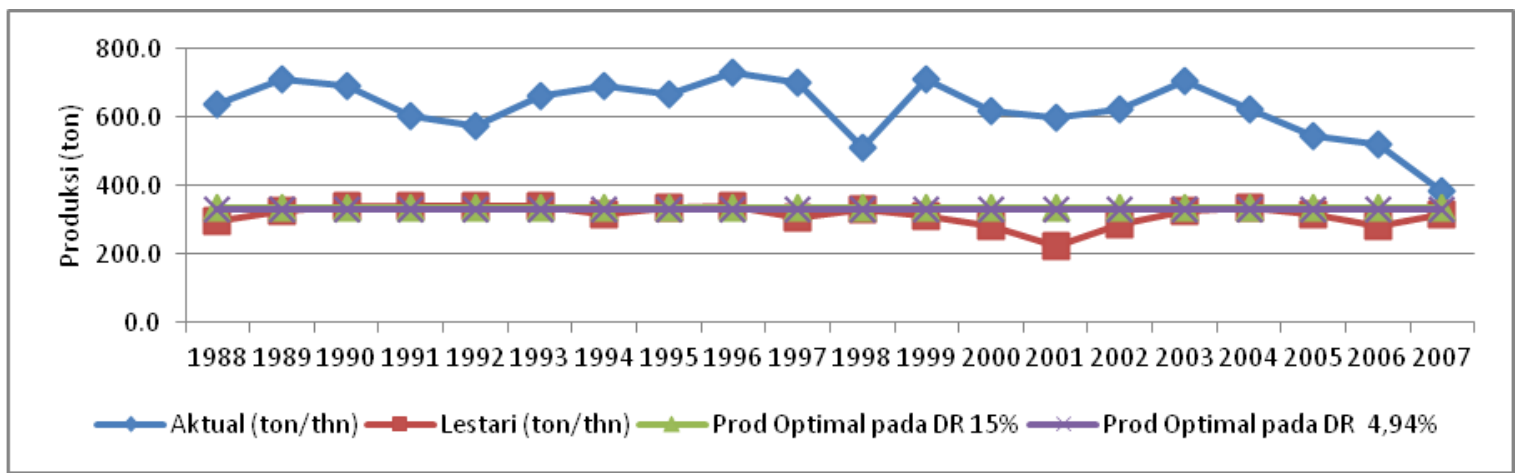

Gambar 13. Perbandingan produksi aktual, lestari dan produksi optimal ikan cakalang pada market discount rate $15 \%$ dan real discount rate $4,94 \%$

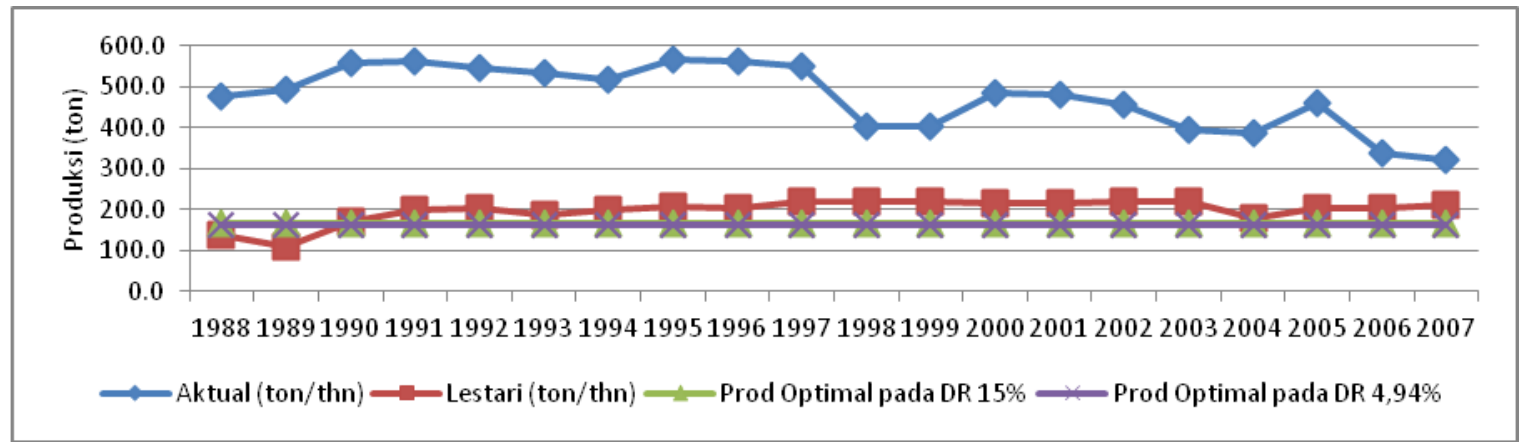

Gambar 14. Perbandingan produksi aktual, lestari dan produksi optimal ikan tuna pada market discount rate $15 \%$ dan real discount rate $4,94 \%$

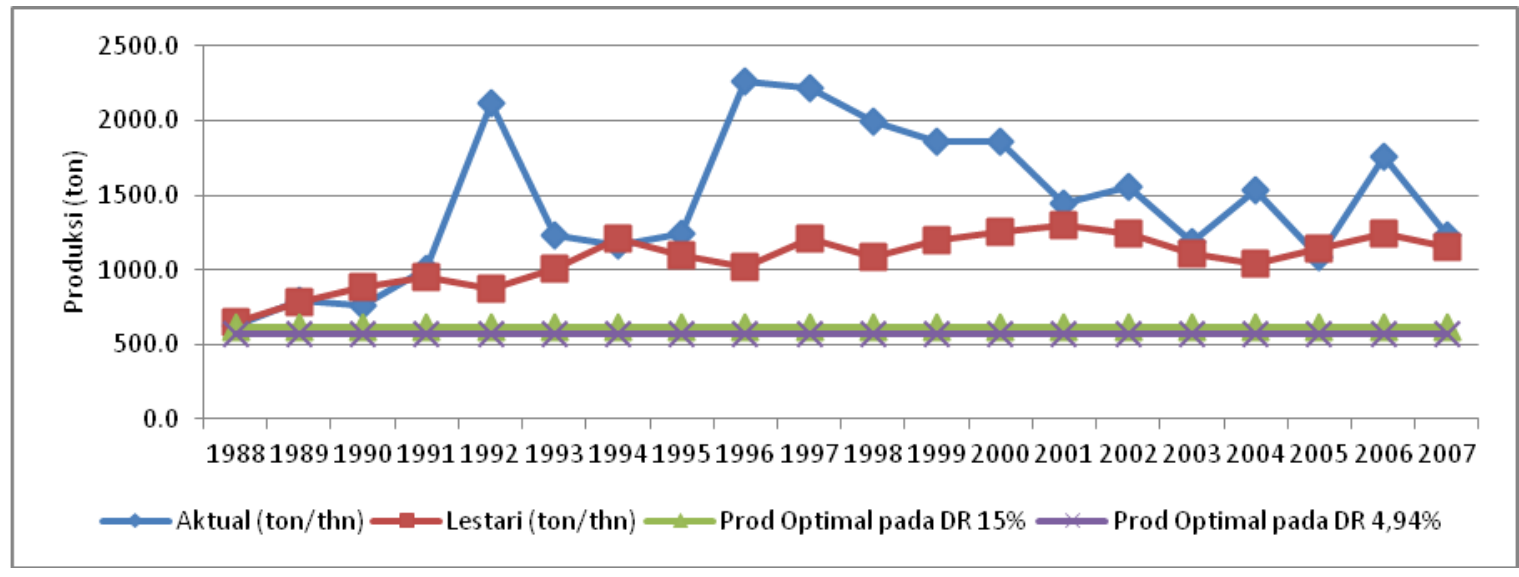

Gambar 15. Perbandingan produksi aktual, lestari dan produksi optimal ikan tongkol pada market discount rate $15 \%$ dan real discount rate $4,94 \%$

Jika sumber daya ikan dikelola secara optimal maka produksi harus mengikuti trajektori optimal dengan input level yang sesuai dengan perhitungan pada real discount rate dari Kula $4,94 \%$ maupun pada market discount rate $15 \%$. Nilai rata-rata total revenue dan nilai present value dari pengelolaan secara optimal disajikan dalam Tabel 9. Dari Tabel 9 terlihat bahwa dari pengelolaan ikan secara optimal diperoleh keuntungan secara optimal untuk keenam jenis ikan yang dianalisis sebesar Rp. 9,72 miliar pada discount rate $15 \%$ dan Rp. 9,48 miliar pada discount rate $4,94 \%$. Nilai ini apabila diukur dengan present value 
diperoleh masing-masing Rp. 64,79 miliar dan Rp. 63,19 miliar.

Tabel 9 juga memberikan arahan bahwa nilai optimal yang tertinggi diraih dari pengelolaan ikan layang, menyusul ikan tongkol dan ikan tongkol, sedangkan jenis ikan cakalang, tuna, selar, dan cucut relatif kecil dalam memberikan saham dalam pengelolaan yang optimal. Pengelolaan optimal memberikan arah yang jelas dalam pengelolaan perikanan di Kepulauan Sangihe agar dapat dilakukan pengelolaan sesuai dengan kondisi ekonomi dan lingkungan.
Sejalan dengan pengelolaan optimal, maka penataan level input untuk pengelolaan perikanan untuk jenis ikan yang dianalisis perlu dilakukan. Sejalan dengan itu maka diperlukan pengkajian effort aktual dan optimal serta sustainable rent dan optimal. Hasil pengkajian membuktikan bahwa untuk mengelola perikanan di perairan Kepulauan Sangihe secara keseluruhan input level dalam pengelolaan ikan yang dianalisis perlu diturunkan. Data perbandingan effort aktual dan optimal untuk perikanan yang dianalisis dirangkum dalam Tabel 10.

Tabel 9. Optimal rent dan present value pengelolaan ikan yang dianalisis

\begin{tabular}{|l|c|c|l|l|}
\hline \multirow{2}{*}{ Jenis ikan } & \multicolumn{2}{|c|}{ Optimal rent } & \multicolumn{1}{c|}{ Present value } \\
\cline { 2 - 5 } & $15 \%$ & $4,94 \%$ & $15 \%$ & \multicolumn{1}{c|}{$4,94 \%$} \\
\hline Ikan layang & 2351,23 & 2186,22 & 15674,83 & 14574,78 \\
Ikan selar & 1453,16 & 1463,51 & 9687,74 & 9756,71 \\
Ikan cucut & 1262,67 & 1284,47 & 8417,79 & 8563,15 \\
Ikan cakalang & 1005,64 & 1019,99 & 6704,28 & 6799,91 \\
Ikan tuna & 1661,33 & 1631,79 & 11075,52 & 10878,63 \\
Ikan tongkol & 1985,33 & 1892,36 & 13235,53 & 12615,77 \\
Jumlah & 9719,36 & 9478,34 & 64795,69 & 63188,95 \\
\hline
\end{tabular}

Tabel 10. Rata-rata perbandingan effort actual dan optimal serta sustainable rent dan optimal $(\delta 15 \%)$ menurut jenis ikan yang dianalisis

\begin{tabular}{|c|c|c|c|c|c|c|}
\hline \multirow{2}{*}{ Jenis Ikan } & \multirow{2}{*}{$\begin{array}{c}\text { Std Effort } \\
\text { (trp) }\end{array}$} & \multirow{2}{*}{$\begin{array}{l}\text { Opt Effort } \\
\text { (trip) }\end{array}$} & \multirow{2}{*}{$\begin{array}{l}\text { Sust Rent } \\
\text { (Rp.Juta) }\end{array}$} & \multirow{2}{*}{$\begin{array}{l}\text { Opt rent } \\
\text { (Rp Juta) }\end{array}$} & \multicolumn{2}{|c|}{$\%$ Perbedaan } \\
\hline & & & & & $\Delta$ Effort & $\Delta$ Rent \\
\hline Ikan layang & 63350 & 50045 & 2365,12 & 2351,23 & $-26,59$ & 2,66 \\
\hline Ikan selar & 55338 & 23230 & 926,25 & 1453,16 & $-50,67$ & 30,56 \\
\hline Ikan cucut & 115157 & 63104 & 200,67 & 1262,67 & $-82,49$ & 79,02 \\
\hline Ikan cakalang & 59068 & 37821 & 557,82 & 1005,64 & $-56,18$ & 37,56 \\
\hline Ikan tuna & 177607 & 81867 & 1037,35 & 1661,33 & $-39,37$ & 29,66 \\
\hline Ikan tongkol & 62478 & 24504 & 1946,05 & 1985,00 & $-58,71$ & 7,49 \\
\hline
\end{tabular}

Dari Tabel 10 tersebut menunjukkan bahwa level effort dalam penangkapan ikan tongkol masih dapat dinaikkan sebesar $58,71 \%$ dari effort yang ada saat ini, dan akan mampu memberikan tambahan pendapatan sebesar $7,49 \%$ dari pendapatan yang ada saat ini. Selanjutnya penurunan level input harus dilakukan untuk pengelolaan ikan layang, sebesar $26,59 \%$ akan meningkatkan pendapatan sebesar $2,66 \%$. Penurunan level input (effort) tertinggi harus dilakukan dalam pengelolaan ikan cucut, ikan cakalang, dan ikan selar masing-masing sebesar $82,49 \%$; 56,18\%; dan $50,67 \%$ secara berturut-turut akan meningkatkan pendapatan sebesar 79,02\%; 37,56\%; dan $30,56 \%$.

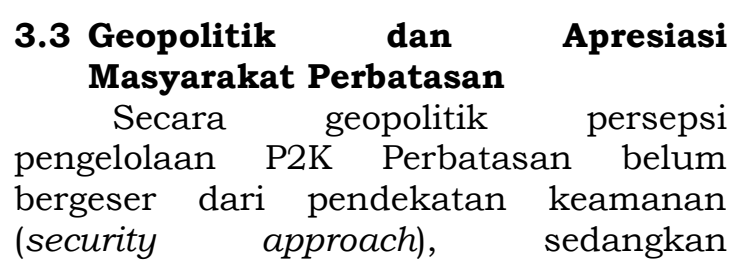


pendekatan kesejahteraan (prosperty) dan lingkungan (environmental) belum memperoleh tempat yang sejajar dengan pendekatan keamanan. Padahal geopolitik adalah wawasan nusantara atau cara pandang sebagai suatu kesatuan. Perdagangan lintas batas (border trade) yang disepakati pada tahun 1965 sebesar US\$ 2500 per trip/orang, dalam kenyataannya terlampaui bahkan sepuluh kali lipat dari nilai semestinya, baik melalui route legal maupun illegal (penyelundupan). Masalah demarkasi dan delimitasi batas juga merupakan bagian yang penting dalam formulasi geopolitik.

Analisis hasil persepsi key person dengan A'WOT yang disaring melalui dasar kebijakan yaitu geopolitik, daya dukung ekonomi dan daya dukung lingkungan dengan menggunakan perangkat analisis Expert Choice menghasilkan sembilan alternatif kebijakan pengelolaan, meliputi: (1) demarkasi dan delimitasi batas negara; (2) pengembangan sistem pertahanan keamanan; (3) penataan hukum dan kelembagaan; (4) peningkatan sarana dan prasarana P2K Perbatasan; (5) pengembangan ekonomi dan perdagangan; (6) pengembangan kawasan ekonomi khusus secara bertahap; (7) penataan ruang laut Kepulauan Sangihe; (8) pemanfaatan SDA secara optimal dan lestari; dan (9) pengawasan dan pengendalian pemanfaatan SDA.

\section{KESIMPULAN DAN SARAN}

Urutan prioritas kebijakan yang dirumuskan pengelolaan P2K Perbatasan Kepulaun Sangihe, adalah sebagai berikut: (1) pengembangan komoditas unggulan seperti ikan tuna, ikan tongkol, ikan cucut, kelapa, dan pala, secara optimal dan lestari; (2) demarkasi dan delimitasi batas negara; pengembangan sistem pertahanan keamanan; dan (4) perubahan materi perjanjian perdagangan perbatasan (border trade agreement, BTA) lebih ekonomis dan berkeadilan. Disarankan agar dilakukan penelitian kembali tentang pemanfaatan SDA dan kerjasama ekonomi berwawasan lingkungan antara Kepulauan Sangihe dengan berbagai negara lainnya melalui pemanfaatan P2K Perbatasan Kepulauan Sangihe.

\section{DAFTAR PUSTAKA}

Anna S. 2003. Model embedded dinamik ekonomi interaksi perikanan pencemaran. Disertasi. Program Pascasarjana, IPB. Bogor.

Clarke RP., Yoshimoto SS., and Pooley SG. 1992. A bioeconomic analysis of the North-Western Hawaiian islan lobster fiheries. Marine Resources Economic; 7 (2): 115140.

Fauzi A. 1998. The management of competing multi species fisheries: a case of a small pelagic fishery on the north coast of Centeral Java (Thesis). Vancouver, Canada, Simon Fraser University. Departement of Economics.

Henley D. 1996. Nationalism and regionalism in a colonial context, Minahasa in the Dutch Indies. KITLV Press, Leiden.

Kamaluddin L. 2002. Pembangunan ekonomi maritim di Indonesia.

Penerbit PT. Gramedia Pustaka Utama Jakarta.

2003. Kebijakan dan implementasi pembangunan kelautan dan pengembangan kawasan/daerah dan pulau-pulau di wilayah perbatasan Republik Indonesia. Makalah disampaikan dalam Seminar Pulau-Pulau Kecil Perbatasan. Dewan Maritim Indonesia, Jakarta.

2003.b. Pemberdayaan pulau perbatasan. Media Indonesia: Kamis 4 September 2003. http://els.bappenas.go.id/upload/o ther/Pemerdayaan\%20. pulau.htm. Dikunjungi 30 Juni 2008.

.2005a. Negara maritim dengan kebijakan prodaratan. Media Pikiran Rakyat tanggal 3 Juni 2005. http://www.pikiranrakyat.com/cetak/2005/0605 /03/0803.htm Dikunjungi tanggal 27 Juli 2007. $2005 b$.

Pembangunan wilayah perbatasan. Republika 19 Maret 2005. http://osdir.com/ ml/ culture.region.indonesia.ppiindia/2005-03/insg01524.html. Dikunjungi tanggal 10 Agustus 2007.

Rawis J. 2004. Menjahit laut yang robek: paradigma "archipelago state" Indonesia: Batam, memaksimalkan 
pendayagunaan pulau kecil: "platform" baru pembangunan kelauatan. Penerbit Yayasan Malesuy, Jakarta.

Riyadi dan Bratakusumah DS. 2003. Perencanaan pembangunan daerah: Strategi menggali potensi dalam mewujudkan otonomi daerah. Penerbit PT. Gramedia Pustaka Utama. Jakarta.

Saaty T L. 1988. Decision Making for Leaders: The Analytical Hierarchy Process for Decision in Complex World. RWS Publications, Pittsburgh. 